\title{
Amphibian chytridiomycosis: a review with focus on fungus-host interactions
}

\author{
Pascale Van Rooij , An Martel, Freddy Haesebrouck and Frank Pasmans
}

\begin{abstract}
Amphibian declines and extinctions are emblematic for the current sixth mass extinction event. Infectious drivers of these declines include the recently emerged fungal pathogens Batrachochytrium dendrobatidis and Batrachochytrium salamandrivorans (Chytridiomycota). The skin disease caused by these fungi is named chytridiomycosis and affects the vital function of amphibian skin. Not all amphibians respond equally to infection and host responses might range from resistant, over tolerant to susceptible. The clinical outcome of infection is highly dependent on the amphibian host, the fungal virulence and environmental determinants. B. dendrobatidis infects the skin of a large range of anurans, urodeles and caecilians, whereas to date the host range of $B$. salamandrivorans seems limited to urodeles. So far, the epidemic of $B$. dendrobatidis is mainly limited to Australian, neotropical, South European and West American amphibians, while for B. salamandrivorans it is limited to European salamanders. Other striking differences between both fungi include gross pathology and thermal preferences. With this review we aim to provide the reader with a state-of-the art of host-pathogen interactions for both fungi, in which new data pertaining to the interaction of $B$. dendrobatidis and B. salamandrivorans with the host's skin are integrated. Furthermore, we pinpoint areas in which more detailed studies are necessary or which have not received the attention they merit.
\end{abstract}

\section{Table of Contents}

1 Introduction

2 The agents Batrachochytrium dendrobatidis and Batrachochytrium salamandrivorans

2.1 History and taxonomy

2.2 Morphology, lifecycle and physiology

2.3 Epidemiology

3 The disease chytridiomycosis

3.1 Clinical signs

3.2 Pathology

4 Pathogenesis

4.1 Colonization of amphibian skin

4.1.1 Interaction with the mucus barrier

4.1.2 Adherence to host surfaces

4.1.3 Invasion of the epidermis

4.2 Impairment of the skin function

4.3 Host defenses against chytrid infection

\subsubsection{Innate immune defenses}

4.3.1.1 Antimicrobial peptides

4.3.1.2 Antifungal metabolites

4.3.1.3 Lysozyme

4.3.2 Acquired immune defenses

4.3.3 Immune evasion by chytrid fungi

4.4 Concepts of susceptibility, tolerance and resistance in chytridiomycosis

4.5 Mediators of chytrid infection dynamics and disease outcome

4.5.1 Host factors

4.5.2 Pathogen virulence

4.5.3 Impact of environmental factors

4.5.4 Co-infection with multiple pathogens

5 Conclusions

Additional files

\footnotetext{
*Correspondence: pascale.vanrooij@ugent.be

Laboratory of Veterinary Bacteriology and Mycology, Department

of Pathology, Bacteriology and Avian Diseases, Faculty of Veterinary

Medicine, Ghent University, Merelbeke, Belgium
} 


\section{Introduction}

Amphibians worldwide are dwindling both in numbers and distribution area. According the latest assessment of the IUCN Red List of Threatened Species (update 2015) at least $41 \%$ of all extant amphibian species is at risk of extinction [1]. Habitat destruction, alteration and fragmentation, commercial over-exploitation for pet-trade and food, introduction of non-native species, infectious diseases and climate disturbance have been identified as stressors of decline [2].

In the late nineties, sudden mass mortalities in amphibian populations from pristine or protected areas were observed. Especially in biodiversity hotspots like Central America, the Caribbean and Australia, amphibians expirienced "enigmatic" declines. The chytridiomycete fungus, Batrachochytrium dendrobatidis, found to parasitize on amphibian skin, was identified as prevailing cause of these amphibian declines (see e.g. [3, 4]). This fungal infection disturbs the vital function of the skin, e.g. respiration and the maintainance of the water balance, and is often lethal [5]. However, the effects of chytridiomycosis on amphibian species and even within one species are variable. While some tolerant amphibians are able to keep infection levels below a lethal threshold and function as carrier species/supershedders of the infective agent, others are susceptible and develop severe lethal disease (see e.g. [6]).

$B$. dendrobatidis is currently present almost everywhere amphibians occur [7]. Until 2010, in Northern Europe it occurred in amphibian populations in a coexistence steady state $[8,9]$, with only rare reports of $B$. dendrobatidis-linked mortality $[10,11]$. Starting from 2010, a steep enigmatic decline was observed in an endangered but stable population of fire salamanders (Salamandra salamandra) in the south of the Netherlands [12]. In 2013, only $4 \%$ of the population remained. None of the mortalities could be attributed to $B$. dendrobatidis or any other known viral or bacterial amphibian pathogen. About forty individuals were removed from their original habitat and kept ex situ for starting up a breeding programme intended for later reintroduction. Finally, a new chytrid fungus named Batrachochytrium salamandrivorans was isolated from the skin lesions of fire salamanders found dead during the Dutch decline event [13]. This novel fungus is currently causing disease outbreaks in, at least, fire salamander populations in the Netherlands [12], Belgium [14] and Germany [15].

Given the huge impact on amphibian populations, chytridiomycosis is sharply phrased as "the worst infectious disease ever recorded among vertebrates in terms of the number of species impacted, and its propensity to drive them to extinction" [2]. Despite this and the plethora of studies focusing on its causative agents, the complex host-pathogen interactions taking place during the act of infecting are far from being understood. With this review we aimed to sketch a general background on host, pathogens and disease and to provide the reader with a comprehensible overview of the complex hostpathogen interactions. At the same time, this opportunity permits to integrate new findings and to identify areas to which future research should be oriented.

\section{The agents Batrachochytrium dendrobatidis and Batrachochytrium salamandrivorans}

\subsection{History and taxonomy}

$B$. dendrobatidis and $B$. salamandrivorans belong to the Chytridiomycota, a phylum of "lower fungi" (Fig. 1a). These primitive microscopic fungi have a non-mycelial morphology, characterized by motile flagellated spores or so-called zoospores. Most chytrid fungi inhabit moist soil or fresh water and are in essence saprobic or parasitic on plants, algae or invertebrates $[16,17]$. B. dendrobatidis and B. salamandrivorans, together with Ichthyochytrium vulgare (a

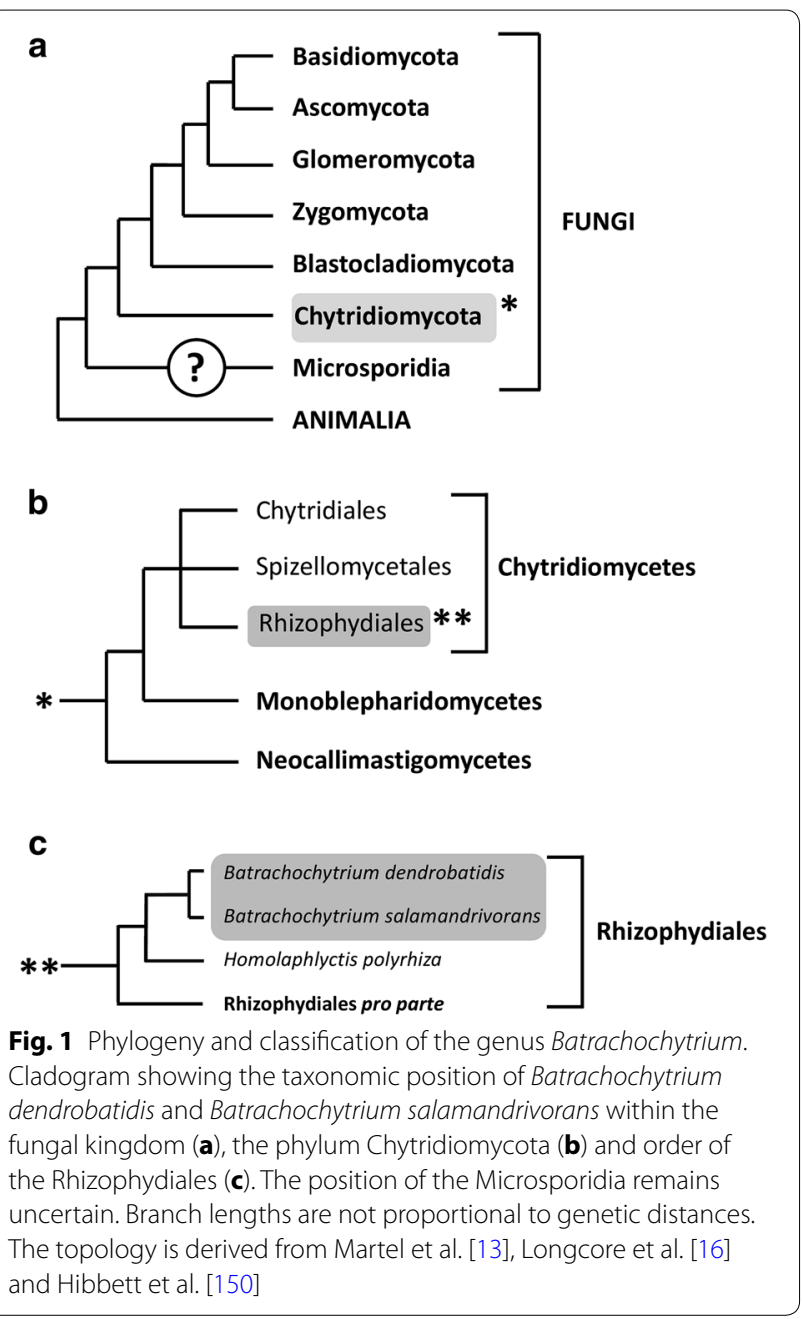


rare parasite in the skin and gills of freshwater fish) [18] are unique within their phylum in infecting vertebrate hosts.

$B$. dendrobatidis and B. salamandrivorans are currently placed in the order of the Rhizophydiales (Figs. 1b and 1c). Their closest relative is the non-pathogenic saprobic Homolaphlyctis polyrhiza (Fig. 1c). Inferred from nuclear protein-coding genes, estimates of when $B$. dendrobatidis diverged from $B$. salamandrivorans run up to approximately 67.3 million years ago [14].

\subsection{Morphology, lifecycle and physiology}

Both $B$. dendrobatidis and B. salamandrivorans have two main life stages as illustrated in Fig. 2: a motile zoospore with a single posteriorly directed flagellum and reproductive body or thallus in which asexual zoospores are produced termed zoosporangium [16]. Sexuality has been scantly documented within the Chytridiomycota [17] and neither $B$. dendrobatidis nor $B$. salamandrivorans have yet been observed in culture to reproduce sexually.
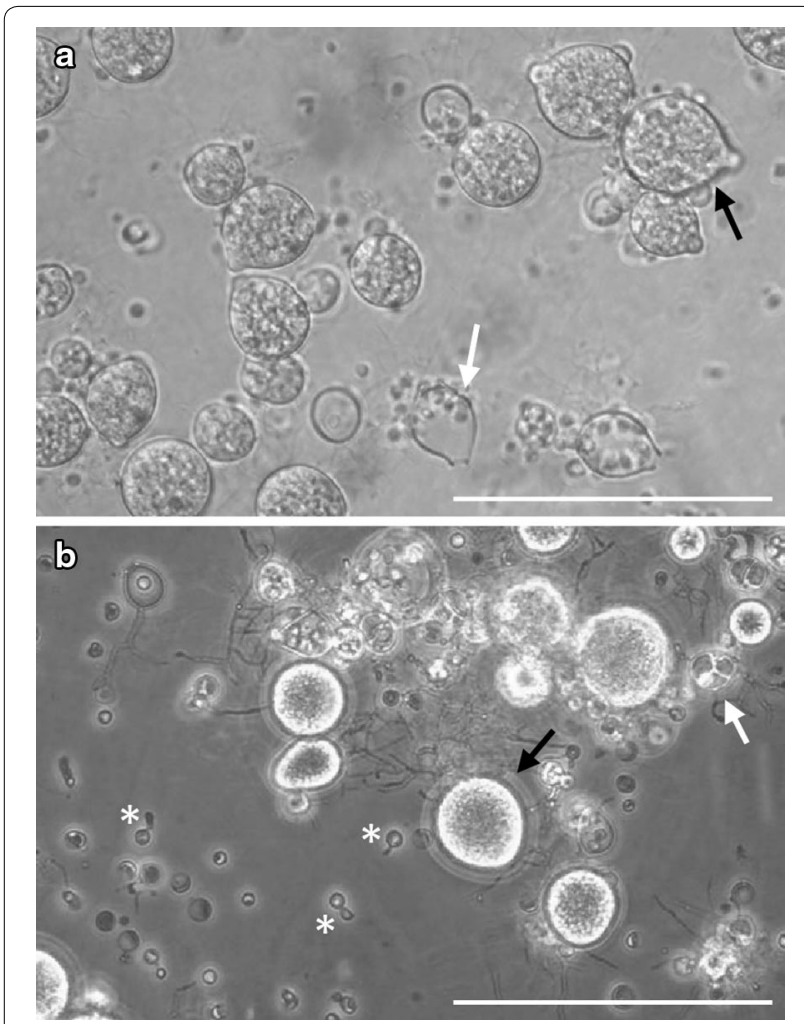

Fig. 2 Morphology of Batrachochytrium species in culture. a Culture of $B$. dendrobatidis on tryptone/gelatin-hydrolysate/lactose (TGhL)-broth, showing abundant mature zoosporangia (black arrow) containing zoospores and empty, discharged sporangia (white arrow); b In culture (TGhL-broth) B. salamandrivorans is characterized by predominant monocentric thalli (black arrow), few colonial thalli (white arrow) and zoospore cysts with germ tubes (asterisk); scale bars $100 \mu \mathrm{m}$
However, as several genetic studies have identified $B$. dendrobatidis isolates with a hybrid genotype, sexual recombination and hybridization must have been important mechanisms in its evolutionary history [19-21]. $B$. dendrobatidis is aneuploid, with copy numbers of the chromosomal regions (contigs) within a single isolate running up to 5 [20-22], while data on the ploidy of $B$. salamandrivorans are lacking.

In vitro, $B$. dendrobatidis thrives best in tryptone-gelatin hydrolysate-lactose (TGhL) broth or $1 \%$ tryptone broth. The lifecycle of $B$. dendrobatidis in culture, from zoospore to zoosporangium takes 4 to 5 days at $22{ }^{\circ} \mathrm{C}$ [23]. B. salamandrivorans grows well in TGhl-broth or broth containing peptonized milk, tryptone and glucose (PmTG) and has a lower thermal preference than B. dendrobatidis; at $15{ }^{\circ} \mathrm{C}$, its lifecycle in culture is completed within 5 days [12]. Their lifecycle in culture is similar. As shown in Fig. 3, the zoospore first encysts by developing a cell wall and absorbing its flagellum, to finally form a germling with fine tread-like rhizoids. The maturing germling develops into a zoosporangium in which the cytoplasm cleaves mitotically to form new zoospores. Zoosporangia are predominantly monocentric (a thallus containing a single sporangium) and rarely colonial (a thallus containing more than one sporangium). Discharge papillae or tubes, blocked inside by a plug, are formed during the growth of the sporangium. At maturity the plug dissolves and the zoospores are released into

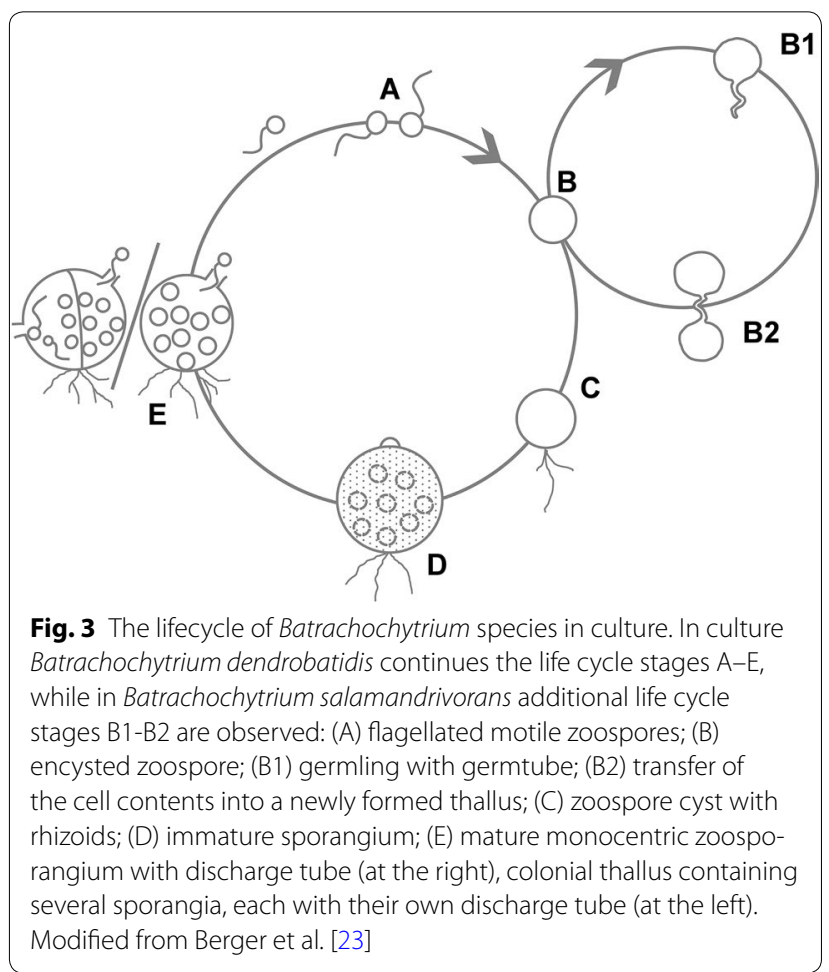


the environment to continue their lifecycle $[16,23]$. Distinctive features of B. salamandrivorans in culture are its lower thermal preference, the presence of tubular extension or germ tubes arising from the encysted zoospores and from which new sporangia arise and the more abundant colonial thalli (shown in Figs. 2b, 3) [12].

The lifecycle of $B$. dendrobatidis in amphibian skin is largely similar to what is observed in culture. Upon colonization of the host epidermis, the zoospores encyst; the flagellum is absorbed and a cell wall is formed [23]. Next, the zoospore cyst germinates and develops a germ tube that invades the host epidermis. At the tip of the germtube a new sporangium arises [24, 25]. Subsequently, the fungus proliferates intracellularly, within the cells of the stratum corneum and the stratum granulosum. Immature sporangia are carried from the deeper skin layers to the skin surface by differentiating epidermal cells. At the time sporangia have developed discharge tubes and contain mature zoospores, they finally occur in stratum corneum where the zoospores are released in the environment $[16,23]$. The lifecycle of $B$. salamandrivorans in amphibian skin has not yet been illustrated in great detail, but is assumed to be similar.

Growth and survival of Batrachochytrium species are strongly temperature dependent. Optimal growth of B. dendrobatidis is observed between 17 and $25^{\circ} \mathrm{C}$ and $\mathrm{pH}$ 6-7 [26]. At $10^{\circ} \mathrm{C}$ or lower, B. dendrobatidis grows slowly. At $28^{\circ} \mathrm{C}$ or higher $B$. dendrobatidis ceases growth, while its zoospores are killed within $4 \mathrm{~h}$ at $37^{\circ} \mathrm{C}[26,27]$. In addition, desiccation is poorly tolerated $[27,28]$ and $5 \% \mathrm{NaCl}$ solutions are lethal [27]. For B. salamandrivorans, the optimum temperatures for growth are between 10 and $15{ }^{\circ} \mathrm{C}$. This chytrid fungus can still grow at $5{ }^{\circ} \mathrm{C}$ while temperatures of $25^{\circ} \mathrm{C}$ and higher are lethal $[13,29]$.

Under laboratory conditions, $B$. dendrobatidis grows on a variety of keratin containing substrates such as autoclaved snake skin, $1 \%$ keratin agar, frog skin agar, feathers and geese paws [16, 26, 28]. However, keratin is not an essential nutrient for this skin attacking fungus: not only $B$. dendrobatidis grows best in tryptone or peptonized milk [16] but also its extracellular proteases fail to degrade keratin in vitro [26]. Besides keratin, B. dendrobatidis is also able to grow on the chitinous carapaces of crustaceans [30]. Like its congener, $B$. salamandrivorans is able to attach and grow on keratinous toe squamae of wild geese (Additional file 1). Notwithstanding, its nutritional needs and preferences remain to be studied in detail.

\subsection{Epidemiology}

B. dendrobatidis has a broad host range and infects at least 520 species of anurans (frogs and toads), urodeles (salamanders and newts) (for details see [31, 32]) and caecilians [33]. Many enigmatic declines and local extinctions of amphibian species in Central-America (with losses up to $40 \%$ of the local species) [4, 34], NorthAmerica [35], Australia [3] and Southern-Europe have been attributed to this fungus [36].

Unlike B. dendrobatidis, B. salamandrivorans seems restricted to salamanders and newts. Essential information on host range and actual distribution of B. salamandrivorans derives from the work of Martel et al. [13, 14]. From the 35 anuran (frogs and toads), urodelan (salamanders and newts) and caecilian species that have been tested under laboratory conditions, none of the anuran or caecilian species became infected. Especially non-Asian salamander species belonging to the family Salamandridae seem highly susceptible for lethal chytridiomycosis, with the majority of the infected animals succumbing within 2-3 weeks after initial exposure. Several recent broad-scaled studies have assessed the extent and impact of $B$. salamandrivorans on amphibian populations worldwide in more than 7000 samples, covering over 170 amphibian species from across 4 continents (Europe, Asia, North-and South America) [14, 37-39]. So far, the distribution of $B$. salamandrivorans seems limited to Western palearctic salamanders, evidenced by disease outbreaks in the Netherlands [12] and Belgium [14] where it reduces populations of (at least) fire salamanders (Salamandra salamandra) below 5\% of their original population size. At one of the Dutch outbreak sites [40] and in Flanders (Belgium), wild specimens of the Alpine newt (Ichthyosaura alpestris) have been found infected with $B$. salamandrivorans, however disease-mediated declines have not yet been recorded for this species. Very recently, B. salamandrivorans outbreaks in captive collections of European salamander species (including Salamandra and Speleomantes spp.) have been reported in the UK [41] and Germany [15].

Where did these fungi originate and how did they spread? So far, the precise origin of $B$. dendrobatidis is unknown. Africa [42], North-America [43] as well as Asia [44, 45] and the Atlantic Forest of Brazil [21, 46] have been suggested as sites of origin. At the moment the Atlantic Forest of Brazil is suggested as cradle of B. dendrobatidis. The Brazilian lineage or genotype of $B$. dendrobatidis $(B d \mathrm{Bz})$ has been enzootic in local amphibian assemblages for at least 100 year and has diverged earliest in the phylogenetic history of the pathogen [21, 46]. But also in Asia, B. dendrobatidis was present more than 100 years ago. Recently, Fong et al. [45] could trace the presence of $B$. dendrobatidis in Korea back to 1911, by analysis of museum specimens. It is therefore not inconceivable that several lineages of $B$. dendrobatidis have an independent history. $B$. salamandrivorans is thought to have its origins in Asia. This fungus occurs historically 
at low levels on salamanders of the families Hynobiidae (Hynobius, Onychodactylus, Salamandrella spp.) and Salamandridae (Cynops, Paramesotriton, Tylototriton spp.) throughout at least Japan, Thailand and Vietnam. The oldest evidence was found in a museum specimen of Cynops ensicauda (sword-tailed newt) dating back from 1861 [14]. Two competing hypotheses are proposed to explain the origin of any emerging infectious disease, including chytridiomycosis [47]. Such a disease may result from a pathogen that has been present historically at a low to moderate prevalence, but is rendered more pathogenic by changes in host susceptibility, virulence and/or environment; this is known as the endemic pathogen hypothesis (EPH). Alternatively, a pathogen may arrive in a new geographic area, whether or not by human-mediated dispersal, and encounter naïve host populations, as stated by the "novel" or invasive pathogen hypothesis (NPH). There has been much debate about which of these hypotheses explain most satisfactorily the current distribution of $B$. dendrobatidis. The prevailing opinion about this issue is that this pathogen has been endemic in some parts of its range and novel in others [21]. Some species/populations appear less susceptible than others: $B$. dendrobatidis has been present in several amphibian populations before declines occurred [42, 45, 48] and endemic amphibian populations may coexist with $B$. dendrobatidis without any obvious signs or marked declines, e.g. in sub-Saharan Africa, Asia, northern Europe and Brazil [9, 42, 45, 46]. Together with evidence of environmental factors influencing disease outbreak [7], these observations favor the $E P H$. Several studies have evidenced that when $B$. dendrobatidis enters a region as an invasive species, amphibian populations decline, in some cases to extinction [4, 34]. More recent studies revealed a much larger genetic diversity in $B$. dendrobatidis isolates than previously recognized, indicating a complex evolutionary history of the pathogen [21, 22].

Regardless of $B$. dendrobatidis's origin, it is clear that the international trade in live amphibians has paved the way to the dispersal of the pathogen between continents $[20,49]$. Especially the African clawed frog (Xenopus laevis) and North American bullfrog (Lithobates catesbeianus) are notorious in this respect. For instance, more than $94 \%$ of the amphibian trade in the US is restricted to L. catesbeianus, with more than 20 million of specimens traded over an 8 years' period [50]. X. laevis is widely traded for scientific research [42], whereas $L$. catesbeianus is imported at large scale to mainly the US, SouthAmerica, China and Europe for consumption [49, 50]. Both species are highly invasive when introduced into new environments [49]. More importantly, X. laevis and $L$. catesbeianus are subclinical carriers of $B$. dendrobatidis infection and act as reservoir, transmitting the infection to naïve native amphibians species [42, 51]. In a recent study, Kolby et al. [52] tested water in which $X$. laevis frogs were transported for the presence of $B$. dendrobatidis and found exceptionally high densities ranging from 3390 to 16887 zoospore equivalent per liter water. It is clear that incorrect disposal of infected wastewater, involves a serious risk of pathogen pollution.

Transmission among hosts is mainly established by the motile waterborne zoospores [16] or through direct contact with infected amphibians (e.g. during mating) [53]. Infected amphibians may shed considerable loads of zoospores into waterbodies, making them potential environmental reservoirs [52, 54]. It is true that, under sterile conditions, $B$. dendrobatidis can survive in water and moist soil for weeks up to several months $[55,56]$. However, little is known on the ecology of free-living $B$. dendrobatidis outside its amphibian host [57] and its ability to persist outside its amphibian host in a natural environment, exposed to micro-invertebrates (see further).

Furthermore, $B$. dendrobatidis is able to saprobically grow on e.g. sterile bird feathers, arthropod exoskeletons, keratinous paw scales of waterfowl and to survive in the gastrointestinal tract of crayfish [16, 28, 30, 55, 56]. Both waterfowl and crayfish have been suggested as potential non-amphibian vectors for $B$. dendrobatidis contributing to the dissemination of $B$. dendrobatidis $[28,30]$. $B$. dendrobatidis DNA has also been found on wild Panamian lizards and snakes [58], albeit it is not clear if $B$. dendrobatidis can persist on reptile skin under natural conditions.

Also B. salamandrivorans was most likely introduced to Europe through amphibian trade. $B$. salamandrivorans was found in imported Asian salamanders. At least five Asian salamander species (Cynops pyrrhogaster, Cynops cyanurus and Paramesotriton deloustali and Salamandrella keyserlingii) could be suitable reservoirs of the disease and are able to shed zoospores for at least 5 months without necessarily developing clinical disease [14]. This is quite worrysome since $B$. salamandrivorans is highly contagious for susceptible salamander species. Cohousing experiments learn that a contact period of $8 \mathrm{~h}$ is sufficient for transmission of B. salamandrivorans from infected Cynops pyrrogaster to naïve individuals and other species [14]. Moreover, especially fire-bellied newts of the genus Cynops are traded in large numbers, exceeding 2 million in an 8-year period [50]. The risk for indroduction of $B$. salamandrivorans in other regions than northernEurope is thus quite realistic. The study of the survival of $B$. salamandrivorans outside its host and its spread in the environment is still a virgin field. Future research should also focus on possible carriers and non-amphibian vectors favoring this pathogen's spread. 


\section{The disease chytridiomycosis}

\subsection{Clinical signs}

In anuran larvae, clinical signs of chytridiomycosis due to $B$. dendrobatidis are generally limited to depigmentation of the mouthparts, without morbidity and mortality $[3,59]$. However, B. dendrobatidis may cause sub-lethal effects, including lethargy or poor swimming abilities, leading to low foraging efficiencies which is reflected in reduction in body size [60]. In metamorphosed amphibians clinical signs are variable and range from sudden death without obvious disease to significant skin disorder but infection may nonetheless elapse asymptomatically. Most common signs of chytridiomycosis are excessive shedding of the skin (Fig. 4a), erythema (redness) or discoloration of the skin [61]. Although uncommon in other species, skin ulcerations occurred in severely infected green tree frogs (Litoria caerulea) [62]. In frogs and toads, the skin of the ventral abdomen, especially the pelvic patch (a highly vascularized skin area on the ventral side of the body), feet and toes are predilection sites of infection $[62,63]$, while in salamanders the pelvic region, fore and hind limbs and the ventral side of the tail seem more prone to infection [64]. Other clinical signs include lethargy, anorexia, abnormal posture (abduction of the hind legs) (Fig. 4a), neurological signs such as loss of righting reflex and flight response [61]. In bolitoglossine salamanders, chytridiomycosis has been associated with tail autotomy (self-induced separation of the tail from the body) [65].

Chytridiomycosis due to $B$. salamandrivorans in metamorphosed urodelans is most strikingly characterized by multifocal superficial erosions and extensive epidermal ulcerations all over the body, as shown in Fig. 5a, b. Coinciding clinical signs include excessive shedding of the skin, anorexia, apathy, ataxia and death [13]. In contrast, the pathogen appears harmless to, at least, urodelan larvae of S. salamandra as experimental inoculation did not result in colonization of the larvae (Additional file 2).

\subsection{Pathology}

In metamorphosed amphibians, chytridiomycosis due to $B$. dendrobatidis is diagnosed by the presence of immature chytrid thalli or maturing sporangia found intracellularly in the keratinized layers of the skin as shown in Fig. 4b, c. Infection is mainly associated with a mild to severe irregular thickening (hyperkeratosis) of the outermost keratinized layers of the epidermis (the stratum corneum and stratum granulosum), erosion of the stratum corneum, and increased tissue growth (hyperplasia) of the stratum spinosum which lies beneath the keratinized superficial skin layers. Also ulceration of the skin may occur [62]. Other pathological changes in the epidermis adjacent to the foci of infection include mild focal necrosis, intercellular edema (spongiosis), cytoplasmic degeneration with minimal to mild inflammation and vacuolation of the deeper cell layers [23]. Dissemination to the deeper layers of the skin or the internal organs does not occur [61]. However, in severely infected Litoria caerulea an atypical pathology including severe congestion of the skin and internal organs may be observed [62]. In anuran larvae, infection is limited to colonization of the keratinized mouthparts and is absent in the epithelia of body, limbs, tail, mouth and gills. Infection is accompanied with minimal pathology, predominantly consisting of mild hyperkeratosis $[3,66]$. Apart from rare exceptions (e.g. in Ambystoma spp.) data about infection in urodelan larvae are lacking. It is noteworthy that in rule urodelan larvae are carnivorous and have true teeth instead of keratinous mouthparts.

In contrast, the pathology corresponding with $B$. salamandrivorans infection in salamanders is quite straightforward. The characteristic erosive skin lesions are associated with the presence of numerous intracellular colonial thalli that spread all over the epidermis and marked necrosis of the adjacent keratinocytes (Fig. 5c, d). Hyperplasia and hyperkeratosis, the hallmarks of $B$. dendrobatidis infection, are absent [13].

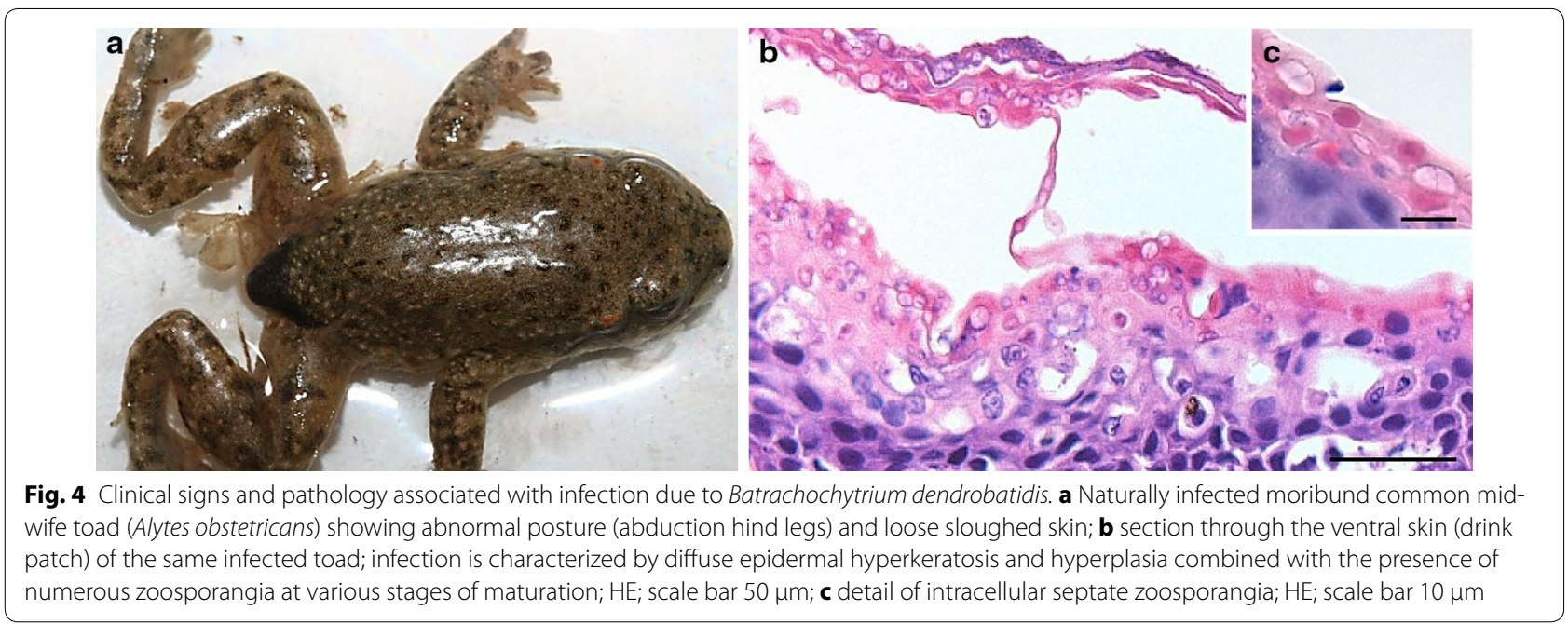



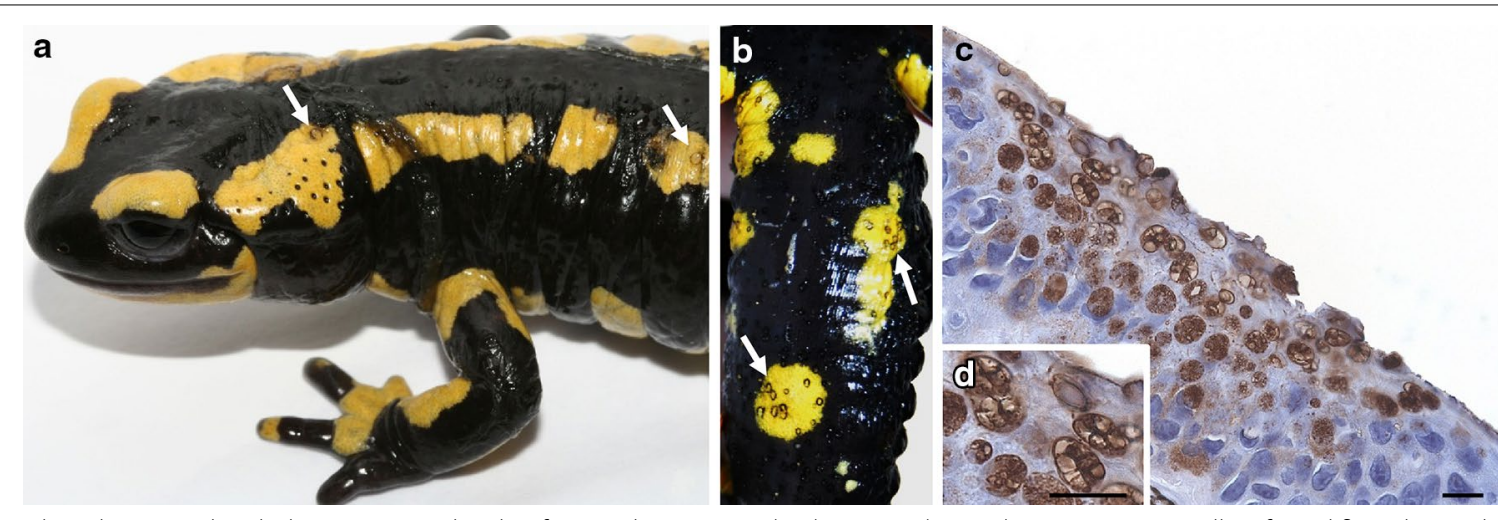

Fig. 5 Clinical signs and pathology associated with infection due to Batrachochytrium salamandrivorans. a a naturally infected fire salamander (Salamandra salamandra) found during a B. salamandrivorans-outbreak (Robertville, Belgium) showing several ulcers (white arrows) and excessive skin shedding; $\mathbf{b}$ extensive ulceration (white arrows) at the ventral side of an infected fire salamander; c skin section through an ulcer evidences abundant intracellular colonial thalli in all epidermal skin layers; immunohistochemical stain with polyclonal antibodies to B. dendrobatidis; scale bar $10 \mu \mathrm{m}$; d magnification of the intracellular colonial thalli from micrograph c; immunohistochemical stain; scale bar $10 \mu \mathrm{m}$

\section{Pathogenesis}

With the availability of $B$. dendrobatidis's full genome, genome based studies have led to an improved understanding of host-pathogen dynamics and the identification of several putative pathogenicity factors with high specificity for skin-related substrates, facilitating colonization or causing host damage. Nevertheless, processes taking place during the whole infection process at molecular and cellular level such as cell signaling, induction of cytoskeletal change and so on, are still less well or barely understood and definitely merit more attention. As research on the recently emerged $B$. salamandrivorans was launched only 2 years ago, our current knowledge is still at its infancy. For now, we are still groping in the dark about, for example, what factors make B. salamandrivorans specific to salamanders and newts, how infection is established and ultimately leads to mortality, and whether or not effective immune responses are elicited during infection. Identification of pathogenicity factors in B. salamandrivorans, involved in its pronounced clinical manifestation and its rapid disease progression, is still long coming. The genome of $B$. salamandrivorans is not yet fully sequenced but whenever available, comparative studies of both fungi's expression profiles may considerably accelerate our insight in factors underlying their differential disease dynamics.

\subsection{Colonization of amphibian skin}

The different steps in the infection process by $B$. dendrobatidis comprise attraction to a suitable host, attachment of zoospores to the host skin, zoospore germination, germ tube development and penetration into the skin cells, followed by invasive growth in the host skin, finally resulting in the loss of the host cell cytoplasm. In this chapter, each of these crucial steps will be discussed in detail.

\subsubsection{Interaction with the mucus barrier}

Directed movement or chemotaxis of flagellated pathogens towards a suitable host and nutrient substrate are often crucial in the establishment of colonization (for review see [67]). There is proof of $B$. dendrobatidis responding positively to certain cues from host or vector origin. Chemotaxis to keratinous toe scales of geese [28] as well as to commercially available keratin and its main constituent amino acid, cysteine [68] has been reported. As numerous bacterial pathogens are found to be attracted to mucus, with some pathogens able to metabolize components of mucus [67], the question arises whether $B$. dendrobatidis could also migrate actively towards the mucous layer covering the amphibian epidermis or one of its components. In search of a suitable amphibian host, $B$. dendrobatidis zoospores indeed will first come into contact with skin mucus. The main component of mucus are mucins or mucin glycoproteins. In the African clawed-frog (X. laevis) the carbohydrate portion of mucins includes the sugars $\alpha$-L-fucose, $\alpha$-D-N-acetylgalactosamine, $\beta$-D- $N$-acetylglucosamine, $N$-acetylneuraminic acid or sialic acid, $\alpha$-D-galactose and

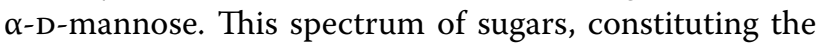
so-called integumental free sugars, was also found in its upper epidermis, and in the epidermises of the caecilian Ichtyophis kohtaoensis, the smooth newt (Lissotriton vulgaris) and the edible frog (Pelophylax kl. esculentus) [69]. Indeed, using a disc method, positive migration of $B$. dendrobatidis towards skin mucus isolated from $X$. laevis was observed (Table 1; also see Additional file 3). Using a capillary tube chemotaxis assay combined with 
Table 1 Chemotaxis of $B$. dendrobatidis zoospores towards mucus and water

\begin{tabular}{|c|c|c|c|c|}
\hline \multirow[t]{3}{*}{ Time (min) } & \multicolumn{4}{|l|}{ Attractans } \\
\hline & \multicolumn{2}{|l|}{ Mucus } & \multicolumn{2}{|l|}{ Water } \\
\hline & Mean zoospores \pm SEM & $\%$ Motile/immobile & Mean zoospores \pm SEM & $\begin{array}{l}\% \text { Motile/ } \\
\text { immobile }\end{array}$ \\
\hline 0 & 0 & 0 & 0 & 0 \\
\hline 45 & $76.8 \pm 64.2$ & 38.1 & 0 & 0 \\
\hline 90 & $152.5 \pm 112.1$ & 29.0 & $0.75 \pm 1.5$ & 25.0 \\
\hline
\end{tabular}

Mean numbers of zoospores with standard errors (mean \pm SEM) and the percentage (\%) of motile zoospores observed in 4 assays, is given for each time point

real-time PCR quantification we found that the free sugars in mucus and amphibian skin are chemotactic (Fig. 6; also see Additional file 4). The odds of $B$. dendrobatidis zoospores being attracted to sugar were approximately 3-9 times higher compared to water (Table 2). Amphibian skin mucus not only offers protection against abrasive damage and dehydration, but is also thought to serve as a critical barrier against colonization by pathogens. Mucus contains several interdependent host factors including antimicrobial peptides (AMPs), lysozymes and mucosal antibodies as well as microbial-community factors, including symbiotic skin bacteria producing antifungal metabolites (for review see [70]), which will be discussed in a later part of this review (Sect. 4.3). This micro-ecosystem of the mucus is referred to as the mucosome. Before zoospores can establish a successful colonization of the host skin, they must first resist the defense factors of the mucosome. The mucosome in its entirety may

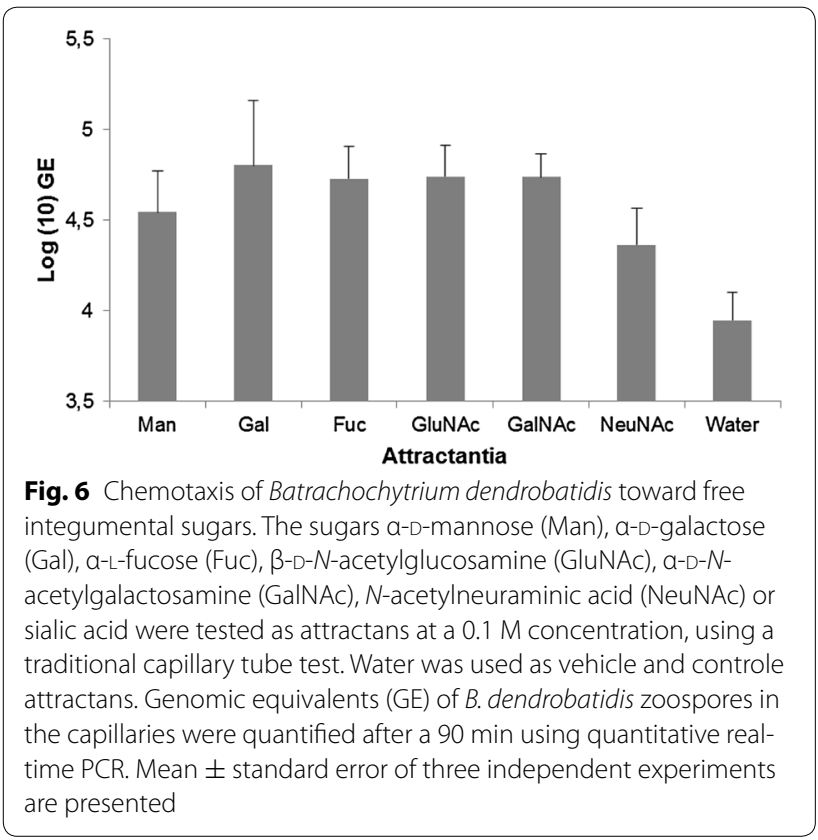

Table 2 Predictors of chemotaxis

\begin{tabular}{llrl}
\hline & OR (A/NA) & $\mathbf{9 5 \% ~ C l}$ & $P$ value \\
\hline Man & 4.93 & $1.77-5.05$ & $<0.0001$ \\
Gal & 9.14 & $8.93-9.30$ & $<0.0001$ \\
Fuc & 6.95 & $6.82-9.96$ & $<0.0001$ \\
GluNAc & 6.59 & $6.45-6.74$ & $<0.0001$ \\
GalNAc & 4.49 & $4.39-4.57$ & $<0.0001$ \\
NeuNAC & 3.02 & $2.94-3.09$ & $<0.0001$
\end{tabular}

For each of the sugars tested, the odds of zoospores being attracted (OR) based on the group ratio attracted (A) versus non-attracted (NA), is given with the corresponding $95 \%$ confidence interval $(\mathrm{Cl})$ and $P$ value

Man mannose, Gal galactose, Fuc fucose, GluNAc N-acetylglucosamine, GaINAc $\mathrm{N}$-acetylgalactosamine, NeuNAc N-acetylneuraminic acid

reduce the infection load on the skin during the first $24 \mathrm{~h}$ that are critical for colonization and establishing skin infection [24]. Indeed, in vitro exposure of B. dendrobatidis zoospores to the skin mucus, covering the epidermis of $X$. laevis, with all residing defenses in physiological concentrations, causes up to a 3 to 20 -fold reduction in the amount of viable zoospores within 2-24 h after exposure (Fig. 7; also see Additional file 5). All in all, these data suggest that skin mucus plays a dual role in pathogenesis: although mucus is attractive for zoospores, it constitutes a defensive barrier, limiting invasion to the underlying epithelium by trapping and reducing the amount of infective zoospores on the skin.

\subsubsection{Adherence to host surfaces}

So far, the mechanisms and kinetics of adhesion of $B$. dendrobatidis to amphibian skin have only received limited attention. Adhesion has been documented in explanted amphibian skin and occurs within 2-4 h after exposure to zoospores [24]. Zoospores mature into thickwalled cysts on the host epidermis and often cluster in foci of infection. Cysts are anchored to the skin surface by fine fibrillar projections as shown in Fig. 8 (also see Additional file 6) that resemble the fibrillar adhesins documented for pathogenic fungi affecting human skin 


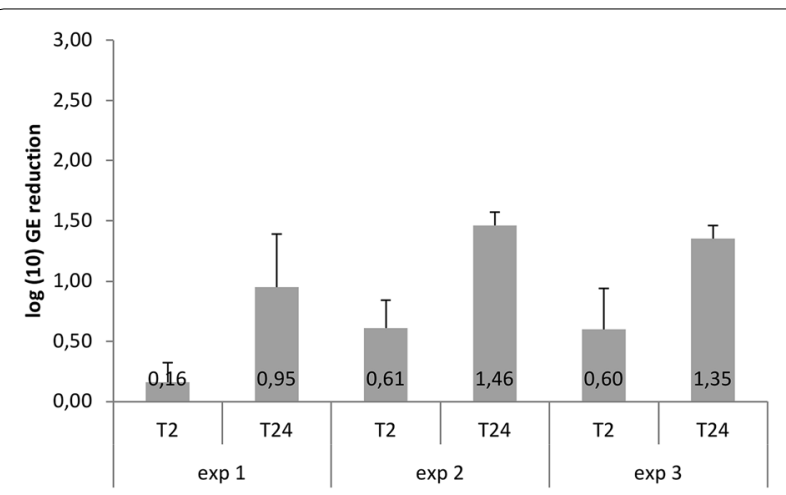

Fig. 7 Zoosporicidal activity of Xenopus laevis skin mucus at physiological concentrations. Killing activity is expressed as log(10) viable spores added to the skin secretions-log(10) viable spores recovered after 2 and $24 \mathrm{~h}$ incubation. Results are presented as mean genomic equivalents of $B$. dendrobatidis \pm standard error (SEM). Sample size (n) for time point $(T)=3$

e.g. Trichophyton mentagrophytes (reviewed in [71]). However, the composition of these fibrils remains to be defined. Several genes encoding proteins involved in cell adhesion such as vinculin, fibronectin and fasciclin have been identified in the $B$. dendrobatidis genome, and are brought more to expression in sporangia than in zoospores [72]. When grown on pulverized host tissue, at least 11 potential adhesion genes which are almost all specific to $B$. dendrobatidis, show an increased expression [73] and require further characterization. The gene expression of $B$. dendrobatidis has not yet been mapped during its early interactions with amphibian skin (neither in vivo nor in vitro) and as such the exact factors mediating adhesion remain uncertain. Adherence mechanisms may include the action of mainly agglutinin-like and

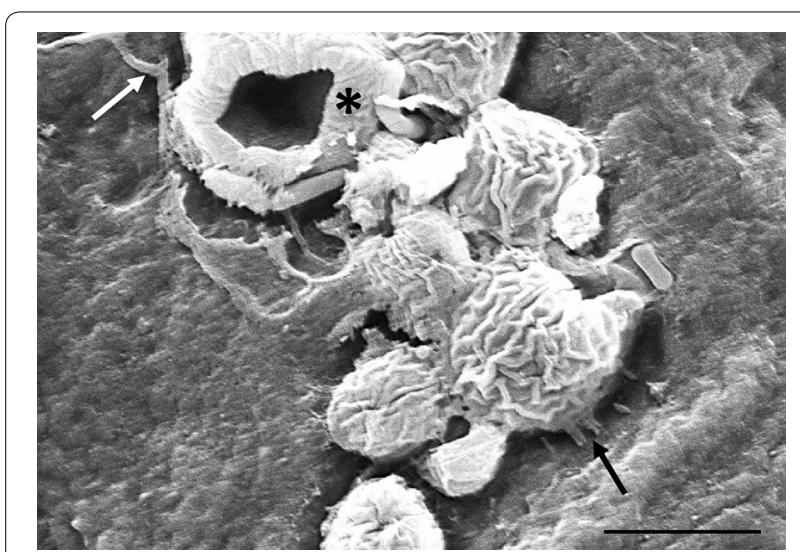

Fig. 8 Adhesion of Batrachochytrium dendrobatidis to Xenopus laevis skin. Adhesion to the epidermal surface is established both by tubular projections, possibly adhesins (black arrow) and rhizoids (white arrow). Some encysted zoospores have collapsed (asterisk) due to cell hollowing; scale bar $5 \mu \mathrm{m}$ lectin-like proteins as described for numerous pathogens. Further research should focus on the identification of adhesins and their respective receptors on the host surface, especially since these insights could open new perspectives for prevention and treatment of chytrid infection.

B. dendrobatidis is equipped with a chitin binding module (CBM18) that is hypothesized to facilitate survival on its amphibian host. Chitin, a polymer of $\mathrm{N}$-acetylglucosamine is the main component of the fungal cell wall. CBM's found in other pathogenic fungi function as competitor of, and limit access for foreign chitinases by binding to the chitin of their proper cell wall. In analogy, a key role of CBM18 in the pathogenesis and protection against host-derived chitinases is suggested. In addition, CBM18 would also allow attachment of the pathogen to non-host chitinous structures (e.g. insect or crustacean exoskeletons) allowing vectored disease spread $[30,74]$.

\subsubsection{Invasion of the epidermis}

The mechanism of host cell entry, intracellular development and spread within the skin has been documented in a skin explant model [24, 75] as well as for experimentally infected frogs [25]. In general, B. dendrobatidis develops endobiotically, i.e. with sporangia located inside the host cell and is achieved within $24 \mathrm{~h}$ after initial exposure. Colonization is established via a tubular extension or germ tube arising from the zoospore cyst that penetrates the host cell membrane and enables transfer of genetic material into the host cell. Then, the distal end of the germ tube swells and gives rise to a new intracellular chytrid thallus. The pathogen then uses the same tactics to spread to deeper skin layers: older "mother" thalli develop rhizoid-like structures spreading to deeper skin layers, form a swelling inside the host cell to finally give rise to a new "daughter" thallus. Figure 9 presents the putative lifecycle of $B$. dendrobatidis in the skin of susceptible amphibian species, resulting from compilation of all available data [2325]. The presence of intracellular chytrid thalli clearly contributes to the disease progression in susceptible animals, but the question remains whether "internalization" of the chytrid fungus aids to evade the innate host defences. As such, more research is needed to define the biological advantage of spreading chytrid propagules to deeper skin layers. Conversely, in explanted skin of the infection tolerant $X$. laevis the pathogen develops merely epibiotically, i.e. with sporangia developing upon the skin (shown in Fig. 10). Here, the affected epidermal cells seem to be solely used as nutrient source for the growing sporangium upon the epidermis [24]. Due to the lack of conclusive histological evidence, it is not 
clear how infections manifest in this species under natural conditions. As this "saprobic" type of development has only been observed in vitro, more observations are necessary.

$B$. dendrobatidis only colonizes keratinized, stratified epidermis. In anuran larvae, colonization is limited to the keratinized mouthparts, i.e. tooth rows and jaw sheats, and is absent in the epithelia fated to keratinize at metamorphosis, i.e. body, limbs, tail, mouth and gills $[3,66]$. Studies in Mixophyes fasciolatus and Osteopilus septentrionalis larvae learn that during metamorphosis colonization of the skin by $B$. dendrobatidis progresses following the distribution of keratin. Shortly before metamorphosis (approx. Gosner stage 38) the epithelia on the feet begin to stratify and keratinize. Then, at metamorphosis (approx.
Gosner stage 40), keratin degrades from the mouthparts before the epithelia on the rest of the froglet's body begin to keratinize. At that time $B$. dendrobatidis infection transitions from the mouthparts to the hindlimbs $[66,76]$.

Our knowledge about the interactions between B. salamandrivorans and its urodelan host is only a minute snippet. The limited number of publications concerning this novel pathogen evidence a rapid disease development in infected urodelans $[13,14]$. Skin invasion correlates with host susceptibility. Inoculation of healthy susceptible salamanders is followed by invasion and intracellular colonization of the skin within $24 \mathrm{~h}$ and can cause mortality within 2 weeks [14]. As B. salamandrivorans develops germ tubes in culture, invasion and spread in the host epidermis is most likely also germ tube mediated,
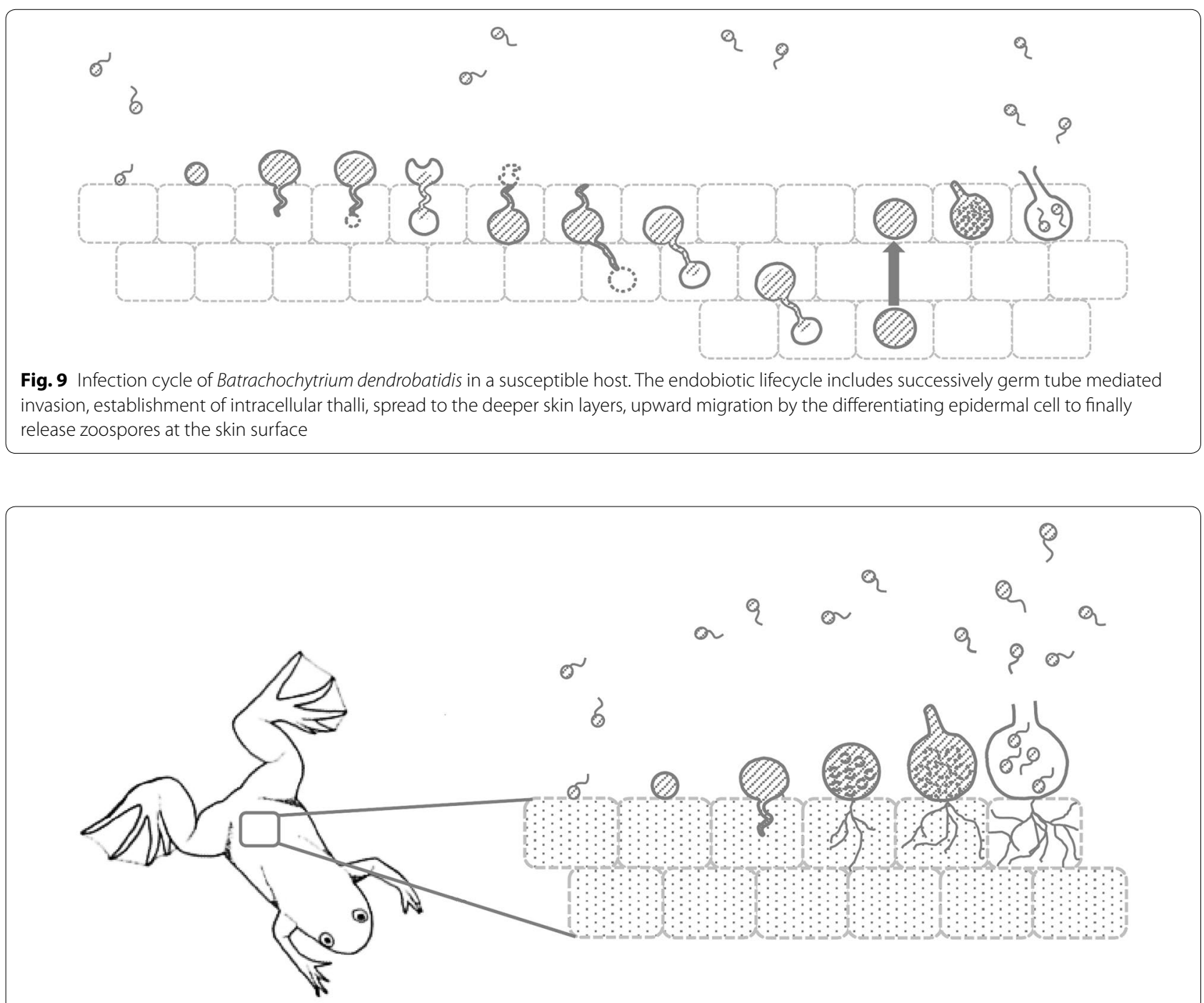

Fig. 10 Epibiotic lifecycle of Batrachochytrium dendrobatidis. The epibiotic lifecycle observed in skin explants of Xenopus laevis includes germ tube mediated invasion, outgrowth of a rhizoidal network, uptake of host cell cytoplasm as nutrient for the growing and maturing chytrid thallus upon the skin surface 
following the same pattern as B. dendrobatidis, but certainly merits further dissection. Due to its particular host specificity, the mechanisms of attraction to the host, host recognition and adherence require further study.

\subsection{Impairment of the skin function}

The skin of amphibians is of vital importance for their survival. Not only it functions as a sensory organ, but also plays an important role in osmoregulation, i.e. the regulation of the osmotic pressure of an amphibians' body fluid, defense, thermoregulation, sex recognition and reproduction. Although most adult amphibians possess lungs, an important part of $\mathrm{O}_{2} / \mathrm{CO}_{2}$ exchange takes place through the skin [77].

We have a quite clear picture of the physical and physiological changes resulting from infection by $B$. dendrobatidis and leading to (lethal) disease, while for its congener, $B$. salamandrivorans, the question remains hitherto unanswered. Severe chytridiomycosis interferes with the skin's vital functions. Impairment starts with the physical disruption of the epidermis. In human pathogenic fungi causing skin infections, extracellular proteases e.g. serine-, aspartyl- and metallo-proteases play an important role in the invasion of the host skin [71]. These digestive enzymes not only cause damage to host tissue but also impair host defenses. B. dendrobatidis possesses a large number of protease encoding genes, that are lacking or far less prominent in its non-pathogenic congeners [21, 78]. In this fungus' genome two gene families were found, encoding a serine-type protease and a fungalysin metallopeptidase, two candidates aiding in host cell invasion and dissolution of cellular cytoplasma. Indeed, in the laboratory, B. dendrobatidis secretes proteases capable of degrading casein, gelatin (a hydrolysed form of collagen) $[26,79]$ and elastin [79]. Additionally, Brutyn et al. [80] discovered that its zoospores secrete a complex mixture of virulence associated proteins including proteases, biofilm-associated proteins and lipases, compromising skin integrity by disturbing the hosts intracellular junctions. Furthermore, infection due to $B$. dendrobatidis triggers a decreased expression of host genes encoding for essential skin integrity components such as keratin, collagen, elastin and fibrinogen [73].

Physical disruption of the epidermis directly affects the osmoregulatory function of the skin: it impairs the electrolyte transport across the skin, accompagnied by a reduction in transepithelial resistance and leakage of ions, giving rise to ion imbalances, and a reduced ability of frogs to osmoregulate or rehydrate. In fact, in blood samples taken from amphibians with clinical chytridiomycosis significantly reduced plasma sodium, potassium and chloride ion concentrations as well as reduced overall blood plasma osmolality have been observed. Especially, low plasma potassium concentrations (or hypokalemia) that are linked to abnormal cardiac electrical activity and cardiac arrest, are thought to be the proximate cause of death in diseased amphibians (for review see [5]). Many fungal and bacterial pathogens are known to alter both structure and function of the host epidermis and induce changes in water and electrolyte transport by activation or inhibition of ion channels and transporters. Electrolyte transport across the amphibian epidermis is partially accomplished by epithelial sodium channels $(\mathrm{ENaC})$ and sodium/potassium pumps. A study by Campbell et al. [5] shows that chytrid infection is likely to inhibit $\mathrm{ENaC}$, leading to a severely reduced sodium absorption through the skin. Whether a toxin secreted by $B$. dendrobatidis itself or changes in enzyme function or protein expression induced by the fungus cause disruption of normal skin functioning, requires further research.

\subsection{Host defenses against chytrid infection}

Both innate and acquired immune components contribute importantly to the antimicrobial function of the mucus, as already pinpointed earlier, and will be elaborated in this chapter.

\subsubsection{Innate immune defenses}

4.3.1.1 Antimicrobial peptides A first innate immune defense mechanism involves the production of AMPs in dermal granular glands. AMPs are small (12-50 amino acid residues), cationic and hydrophobic peptides that can reorganize into an amphipathic (with both a hydrophobic and hydrophilic portion within the same molecule) $\alpha$-helix when bound to charged residues on target cell membranes. Resulting peptide complexes interact with and penetrate into the cell membrane. The mechanisms of AMP action are under debate and both membrane disruption and cell internalization followed by disruption of intracellular targets have been proposed [81]. Most of our current knowledge concerning amphibian AMPs stems from studies on Anura. Although a vast number of wellstudied species lack conventional AMPs (for review see [82]), there is a plethora of data underscoring the effectiveness of AMPs in skin secretions as first line defense against $B$. dendrobatidis, reducing the infection load on amphibian skin to tolerable levels or even clearing them from infection (e.g. [83, 84]). It is not known to which degree anuran AMPs are effective against B. salamandrivorans. To date approximately forty anuran AMPs inhibiting B. dendrobatidis have been characterized [84]. Both purified and natural mixtures of these AMP's effectively inhibit in vitro growth of both $B$. dendrobatidis zoospores and sporangia [83-85]. As the infective spores of B. dendrobatidis lack a cell wall, disruption of the cellular membrane integrity has been hypothesized [70]. However, it is not clear to which extent these peptides provide protec- 
tion against chytridiomycosis in vivo. Species with peptides active in vitro such as the mountain yellow-legged frog (Rana muscosa) may turn out to be very susceptible for infection in nature [86]. Moreover, the efficacy of skin peptide defenses may vary at species and population level [83, 87]. Also little is known about the activity of AMPs once they are secreted upon the skin. Degradation dynamics of skin peptide defenses in species of the Pelophylax complex and in the Northern leopard frog $(L$. pipiens) suggest that once peptides are secreted upon the skin they stay active up to $1-2 \mathrm{~h}$, but are then degraded by host proteases [88, 89]. Unlike for anurans, information about the AMP arsenal in skin secretions of urodelans is scant. In several salamanders species, the antimicrobial action of skin secretions has been attributed to antimicrobial compounds, most probably including AMPs [90, 91]. However, to date only a single antimicrobial peptide (the defensin CFBD) has been described from Cynops fudingensis (Fuding fire belly newt) [92], leaving a wealth of novel AMPs to be discovered. To our knowledge, the antimicrobial action of CFBD against both Batrachochytrium species has not (yet) been evaluated. Although published data are virtually lacking, AMPs may be involved in the anti- $B$. dendrobatidis activity of salamander skin secretions $[90,91]$ and potentially play a role in defense against B. salamandrivorans.

4.3.1.2 Antifungal metabolites A second innate immune defense against $B$ dendrobatidis infections is provided by secondary metabolites secreted by symbiotic bacteria present on amphibian skin. So far, only 3 inhibitory metabolites secreted by the skin bacterial species Janthinobacterium lividum, Lysobacter gummosus and Pseudomonas fluorescens have been identified, i.e. 2,4-diacetylphloroglucinol (2,4-DAPG), indol-3-carboxaldehyde (I3C) and violacein [93]. These antifungal metabolites aid to maintain infection loads below a lethal threshold and exhibit a dual action. First, these metabolites can inhibit growth of $B$. dendrobatidis both in vitro and in vivo [93-95]. However, it is unknown to what extent these metabolites can inhibit B. salamandrivorans. Besides, co-culture of skin bacterial isolates can ultimately lead to secretion of new, more potent metabolites then when grown in monoculture. As such, the inhibitory metabolite tryptophol was found to emerge from co-culturing an unknown Bacillus skin bacterium and Chitinophaga arvensicola [96]. Similarly, Myers et al. [94] discovered that these metabolites work synergistically with AMPs to inhibit growth of $B$. dendrobatidis, at lowered minimal inhibitory concentrations (MIC) necessary for inhibition by either metabolites or AMP's. In addition, the metabolites 2,4-DAPG and I3C seem to exert a repellent action on $B$. dendrobatidis zoospores [97]. As for AMPs, variation in pathogen suscepti- bility among populations is thought to result in part from differences in bacterial skin communities. By comparing bacterial communities on the skin of a declining Rana muscosa population and a population coexisting with $B$. dendrobatidis, researchers found a significantly higher number of individuals with culturable bacterial species displaying antifungal properties in coexisting populations than in those at decline. Alteration of this microbial community composition, for example by environmental factors, can considerably increase susceptibility to disease [95]. Conversely, the team of Harris [98] found that addition of the beneficial skin bacterium J. lividum to the skin of susceptible $R$. muscosa frogs before experimental exposure to $B$. dendrobatidis, considerably alleviated symptoms of chytridiomycosis and prevented morbidity and mortality. However, mitigation of chytridiomycosis using probiotics will prove challenging as not all symbiotic skin bacteria exhibit broad-spectrum inhibition across isolates of a hypervirulent, globally spread $B$. dendrobatidis lineage (BdGPL) [19, 99].

4.3.1.3 Lysozyme Another compound with fungicidal potential in amphibian skin mucus is lysozyme [70], but has hitherto not been studied in detail. The natural substrate of lysozyme or murimidase is peptidoglycan, a major component of the bacterial cell wall and polymer of $\mathrm{N}$-acetylglucosamine (GlcNAc) and $\mathrm{N}$-acetylmuramic acid units. By splitting the $\beta-1,4$ bonds lysozyme causes cell lysis. As the fungal cell wall consists mainly of chitin, a polymer of $\beta-1,4$ linked GlcNAc units, it is also a potential target for lysozyme. Although we detected lysozyme or lysozyme-like proteins in mucus from $X$. laevis, preliminary MIC assays using commercial lysozyme from chicken egg white (1-128 U/mL), failed to demonstrate any fungicidal effect against $B$. dendrobatidis (Additional file 7). More studies in this domain are necessary to draw further conclusions.

\subsubsection{Acquired immune defenses}

Unlike the innate immune system, the acquired or adaptive immune system provides highly specific protection against pathogens. This immunity strategy involves both cell-mediated and antibody responses. However, what has puzzled many researchers is the apparent absence of a robust immune response in susceptible amphibian species. Mapping of transcriptomic changes in immunological important tissues (skin, liver, spleen, small intestine) from frogs diseased with $B$. dendrobatidis, evidence a decreased expression of immunity-related genes (associated with e.g. lymphocytes, Toll-like receptors, complement pathways) $[100,101]$ or even a lack of protective response by the adaptive immune system [102]. Besides, there is conflicting information about whether or not a 
protective immune response can be elicited in amphibians. So far, attempts to immunize frogs by subcutaneous or intraperitoneal injection of formalin (Rana muscosa, see [103]) or heat-killed B. dendrobatidis (Bufo boreas, see [70]) failed to elicit an acquired immune response against $B$. dendrobatidis. Only in X. laevis, B. dendrobatidis-specific IgM, IgX (mammalian IgA-like) and IgY (mammalian IgG-like) antibodies were found in skin mucus after injection with heat-killed zoospores [85]. Usually, antibodies play an important role in neutralizing pathogens or presenting them to other components of the immune system for destruction [70]. In vitro, the mucosal antibodies elicited in $X$. laevis frogs indeed bind with $B$. dendrobatidis zoospores and are suggested to limit colonization of the skin to mild and non-lethal infections [85], but their contribution to real-time protection remains to be determined. As $B$. dendrobatidis infections naturally occur in the skin, it seems likely that introduction of $B$. dendrobatidis antigens directly into the skin and targeting immune effectors in the skin may be more effective [70]. However, evidence for effectiveness of vaccination in form of prior infection by topical exposure of the skin to live or heat-killed B. dendrobatidis is mixed. Several studies have reported a higher survival, reduction in the infection load or complete clearance in frogs that have been repeatedly exposed to $B$. dendrobatidis than in immunologically naïve frogs $[85,104]$, while in others pre-exposure had no such effect [105]. To our knowledge, immunization of salamanders against $B$. salamandrivorans has not yet been attempted.

\subsubsection{Immune evasion by chytrid fungi}

Evasion of host immune recognition and inhibition of antifungal defenses are commonly seen in fungal pathogens. Also for $B$. dendrobatidis there is ample proof of active suppression of host responses coming from genetic, peptidomic, in vitro and in vivo-immune studies [100-102, 106-109].

Ellison et al. [101] found that in highly susceptible harlequin frogs (Atelopus zeteki) B. dendrobatidis-specific immune responses are indeed elicited, but are not effective. Ineffective immune pathway activation and antibody production have been suggested as underlying mechanisms [101]. A breakthrough in research was the discovery that $B$. dendrobatidis cripples the lymphocyte mediated response $[108,109]$. Apparently, soluble factors in $B$. dendrobatidis culture supernatant inhibit lymphocyte proliferation and induce apoptosis, most probably by activating apoptosis signaling pathways. These inhibitory factors have not yet been fully characterized, but seem of non-protein nature, and broadly cytotoxic. Soon after that, the same research team found that this immunosuppression is not absolute. There is proof that increased lymphocyte proliferation and abundance in the spleen can be achieved by repeated pathogen exposure and temperature-induced clearance of infection (i.e. exposure of infected amphibians for longer than $24 \mathrm{~h}$ to $30^{\circ} \mathrm{C}$ which is the critical thermal maximum for $B$. dendrobatidis). As such, at least Oak toads (Bufo quercicus), Cuban treefrog (Osteopilus septentrionalis) and booroolong frogs (Litoria booroolongensis) do acquire immunity to the chytrid fungus, that overcomes $B$. dendrobatidis-induced immunosuppression [104].

Also inhibition of AMP release from dermal granular glands and selective degradation of AMP's by fungal proteases have been suggested to contribute to reduced skin defenses against $B$. dendrobatidis (e.g. [106]). Thekkiniath et al. [110] discovered a particular subtilisin-like serine protease secreted by $B$. dendrobatidis, able to cleave certain amphibian antimicrobial peptides (AMP). Inactivation of the protective function of AMPs by pathogen-derived proteases, is a common strategy in pathogenic bacteria and fungi and contributes significantly to pathogenesis.

\subsection{Concepts of susceptibility, tolerance and resistance in chytridiomycosis}

Not all amphibians respond equally to a chytrid infection and host responses can be roughly categorized as susceptible (infection resulting in disease, either followed by clinical recovery or by mortality), tolerant (persistent infection in absence of disease) or resistant (inhibition or fast clearance of infection). In chytrid-literature the term resistant (pathogen-inhibiting or pathogen-limiting) is often used for describing species that are actually tolerant (damage-limiting) and definitions may vary according to the author. More importantly, this classification is rather controversial as host susceptibility is more likely to fall along a continuum where the response of a species, population or individual host to $B$. dendrobatidis (and probably also $B$. salamandrivorans) is dictated by myriad other factors inherent to host, pathogen and environment than infection dose only. In the next paragraphs we will give some examples for each host response category. However, bearing in mind that susceptibility may vary within a species, this representation may oversimplify reality and the distinction drawn between resistant and tolerant may be disputable.

Clinical chytridiomycosis due to $B$. dendrobatidis appears to mostly occur in anurans. In truly susceptible anuran species, exposure to $B$. dendrobatidis under laboratory conditions to initial low doses of 100 zoospores can lead to $100 \%$ mortality of the experimental animals [111] and in the wild, exposure to B. dendrobatidis can lead to sharp declines and even extinction of a given species. In particular species that live and/or breed in 
permanent water or streams at higher elevations seem most susceptible. Striking examples include the neotropical toad genus Atelopus (harlequin frogs) which is by far the most threatened clade of amphibians with at least 30 of the 97 species presumably extinct [1] and the family of the Myobatrachidae with several taxa that are critically endangered (Tautodactylus, Pseudophryne) or suspected to be driven extinct by $B$. dendrobatidis (gastric brooding frogs in the genus Rheobatrachus) Other taxa susceptible for chytridiomycosis and sufferning from population declines/crashes can be found within, but are not limited to, the families Alytidae (e.g. Alytes and Discoglossus), Bombinatoridae (e.g. Bombina), Bufonidae (e.g. Incilius periglenes, Epidalea calamita, Anaxyrus boreas), Craugastoridae, Dendrobatidae, Hylidae (e.g. Litoria caerulea, Litoria chloris, Litoria genimaculata), Leiopelmatidae (e.g. Leiopelma archeyi), Leptodactylidae (e.g. Leptodactylus fallax), and Ranidae (e.g. Lithobates chiricahuensis, Rana muscosa, Lithobates yavapaiensis, Lithobates tarahumarae) [1, 32]. Far less research has been conducted on salamanders. Lethal chytridiomycosis has been reproduced experimentally only in a very small number of urodelan species, e.g. Batrachoseps attenuatus [112], Bolitoglossa rufescens [34], Plethodon metcalf [113] and Tylototriton asperrimus [114]. Although chytridiomycosis in wild salamander populations has been described, for example in fire salamanders ( $S$. salamandra) in Central Spain [36] and the endangered Sardanian newt Euproctus platycephalus [1, 115], the impact on population level seems by far less obvious and long-lasting than in susceptible anuran populations. One potential exception are Central American populations of plethodontid salamanders (Plethodontidae), which may also be strongly declining due to chytridiomycosis $[4,34$, 64, 65]. Regarding B. salamandrivorans, especially nonAsian Salamandridae seem highly susceptible. So far, one known exception to this rule is the palmate newt (Lissotriton helveticus), which is resistant to B. salamandrivorans while infections are lethal to its close relative, the italian newt (Lissotriton italicus), with mortality occurring approximately 10 days after exposure [14]. In B. salamandrivorans susceptible urodelans, disease can evolve in two opposite directions: clinical recovery or mortality. Although some Asian representatives of the Salamandridae family (i.e. Cynops pyrrhogaster, Cynops cyanurus, Paramesotriton deloustali) are classified as "susceptible", they are capable of limiting clinical disease. In experimentally infected individuals, infection either persists for up to at least 5 months, with infection loads up to $10^{3}$ zoospores and with recurring episodes of clinical disease, or is totally cleared [14].

Tolerant species are able to limit the fitness consequences of infection. Species belonging to this host response category do not succumb to $B$. dendrobatidis infection either in the wild, or under laboratory conditions, although they may be persistently infected. Therefore, they may act as carriers. While prevalence data for $B$. dendendrobatidis are abundant, information on the magnitude of the infection loads these carriers bear is scarce. From available data, the infection loads in naturally infected tolerant species such as Xenopus laevis (African clawed frog) [48, 116] and Lithobates pipiens (the Northern leopard frog) [117] are low (up to 200 zoospores). However, other tolerant species such as the widespread invasive Lithobates catesbeianus (bullfrog) and Pseudacris regilla (the pacific chorus frog) seem to be "supershedders". In naturally infected bullfrogs, detected infection loads can run up to $10^{5}$ zoospores [51], while in experimentally infected $P$. regilla infection loads amount up to $10^{4}$ zoospores and are maintained over a 4-month period [54]. Both species may carry extremely high pathogen burdens without morbidity or mortality, which are lethal to most other species.

Truly resistant species for $B$. dendrobatidis infection are quite scarce. The European cave salamanders (Speleomantes spp.) seem to be a striking example of resistant species as $B$. dendrobatidis is not able to get grip on the skin, probably due to its highly efficient skin defences. In this species, experimental infections are cleared within 7-14 days and despite large sampling efforts there is zero prevalence of $B$. dendrobatidis infections in the wild despite the presence of an aggressive $B$. dendrobatidis lineage (BdGPL) within its geographical range [91, 115]. Truly resistant species for $B$. salamandrivorans include all so far surveyed anurans and caecilians, and several urodelan species belonging to Asian hynobiid, ambystomatid and North-American plethodontid families [14, 37-39].

\subsection{Mediators of chytrid infection dynamics and disease outcome}

As discussed in Sect. 4.3 the amphibian immune system plays a crucial role in confering resistance or tolerance to chytrid infection. However, there is still considerable variation in the response of a species, a population or an individual host to chytrid infection, that cannot be explained by variation in host defenses only. In this chapter we will highlight how slight changes in host, pathogen and environment, whether or not with direct repercussions on the immune system, may affect an individual's or a population's vulnerability to infection.

\subsubsection{Host factors}

The genetic make-up of the host may largely determine the outcome of $B$. dendrobatidis infection. In vertebrates, major histocompatibility complex (MHC) loci encode 
cell-surface receptors regulating the acquired immune response. In amphibians, individuals with specific MHC genotypes, seem to benefit from a higher survival rate when infected by $B$. dendrobatidis [118]. Indeed, specific conformations of the MHC molecules may promote binding to $B$. dendrobatidis antigens. Recently, Bataille et al. [119], found that at least one specific MHCII conformation (pocket 9) functions as adaptive marker for resistance to $B$. dendrobatidis. In contrast, a low genetic diversity within a species or population and consequent reduced biological fitness, may complicate the ability of a species or population to fight $B$. dendrobatidis infection [120].

Furthermore, there seems to be a direct correlation between the body temperature of frogs and their vulnerability to $B$. dendrobatidis infection. A temporary rise in body temperature above $25{ }^{\circ} \mathrm{C}$ may negatively affect $B$. dendrobatidis, since this thermal regime is suboptimal for the pathogen or, as suggested, since elevated body temperatures favour the immune response and thus promote survival. However, it is not clear whether these acute changes in body temperature are related to digestion, growth, reproduction or short exposure to a warm microhabitat [121] and coincidentally affect vulnerability for infection. Alternatively, this physiological response may be driven by pathogen recognition (so-called behavioural fever) which has been reported in a variety of invertebrates and ectothermic vertebrates [122]. There is also proof of amphibians acquiring behavioural resistance. In the study of McMahon et al. [104] frogs were more reluctant to avoid substrates infected with $B$. dendrobatidis after having been exposed to the fungus only once, followed by temperature induced clearance than naieve frogs.

Individual stress levels may also influence the outcome of infection. The glucorticoid stress hormone corticosterone increases due to physiological stress and is in charge for altering the host's physiology and its susceptibility to a pathogen. Several studies have shown a positive correlation between increased stress levels and infection intensity [123]. However, the effect of stress seems to vary with the life history stage and species. In the study of Searle et al. [124] exogenous exposure of Anaxyrus boreas and Lithobates catesbeianus larvae and both larvae and postmetamorphs of Rana cascadae to corticosterone did not alter their susceptibility to infection. The interactions between environmental change, stress hormones and infectious diseases are complex, and it is not quite clear whether higher corticosterone levels due to e.g. changes in the environment, metamorphosis, breeding make individuals more susceptible to infection or if infection triggers higher corticosterone levels.
Differential susceptibility for infection is observed between larval, post-metamorphic, sub-adult and adult stages. For example, tadpoles of Rana muscosa can be infected by $B$. dendrobatidis without developing clinical symptoms, while in post-metamorphic animals infection induces morbidity and mortality [59]. Alternatively, $B$. dendrobatidis can negatively affect some species of amphibians at the larval stage and not others [125]. Also larvae and adult salamanders might display a differential susceptibility for infection with $B$. salamandrivorans. There are several plausible explanations for these phenomena. Just at metamorphosis the larval epidermis begins to stratify and keratinize, a process that is controlled by the thyroid hormone triidodothyronine (T3). Increased hormone levels during metamorphosis (e.g. T3, coricosteroid hormones), may trigger immune suppression and an increased susceptibility to chytrid infection $[110,126]$. But also, at metamorphosis the immune system undergoes a dramatic reorganization, and in newly metamorphosed frogs immune defenses are not yet mature [126].

Finally, it is important to distinguish between individual and population level effects of chytridiomycosis. Infection may cause morbidity and mortality at individual level, ultimately leading to population decline but may just as well go unnoticed. In populations where $B$. dendrobatidis has a high impact on adult survival, increased recruitment (i.e. entry of new individuals into a population by reproduction) may be an important compensatory strategy allowing a population to recover from disease driven decline, even despite the endemic presence of $B$. dendrobatidis $[127,128]$. Compensatory recruitment is only successful when $B$. dendrobatidis has a minimal impact on larvae and juveniles, combined with succesful mating by first time breeders before large increases in disease prevalence and intensity occur [128]. Moreover, populations left at low densities after diseasedriven decline may recover due to altered disease dynamics; in the case of chytridiomycosis high population densities are likely to promote a rapid build-up of infection intensity and continuous reinfection of (infected) individuals [129]. More importantly, the complexity of the amphibian community may affect disease risk. This is known as the "dilution effect": increased species richness, of both hosts and non-hosts, will reduce the impact of B. dendrobatidis (infection prevalence and intensity), by affecting host-pathogen contact rates and transmission [130].

\subsubsection{Pathogen virulence}

The virulence of $B$. dendrobatidis or its relative capacity to cause damage to its amphibian host, is isolate and 
genotype dependent $[19,131,132]$. So far, at least 6 major $B$. dendrobatidis lineages are being recognized, including a hypervirulent global panzootic lineage (BdGPL) [19, 20, 44]. Unlike non-GPL strains, this invasive lineage is associated with massive declines and extinctions that spread in a wave-like manner once introduced into a new area and was involved in the major epizootics in the Americas, Australia, and Europe (Spain, French Pyrenees). As there are currently no isolates available from endemic northern-european amphibian populations coexisting with $B$. dendrobatidis, the genotype(s) circulating in this area is/are unknown. Yet, further collection of isolates, of both $B$. dendrobatidis and B. salamandrivorans, is of vital importance for gaining insights in the evolution of virulence.

Virulence of $B$. dendrobatidis increases experimentally with ambient temperatures below $25{ }^{\circ} \mathrm{C}$. As discussed earlier, optimal growth of $B$. dendrobatidis occurs within a temperature range of $17-25^{\circ} \mathrm{C}$. Within this range, zoospores encyst and develop into zoosporangia faster than at low temperatures. However, at low temperatures, a larger number of zoospores is produced per zoosporangium, with zoospores remaining active and thus infective for a longer period [133]. As a consequence, mortality in naturally infected amphibians will be considerably higher, in the cooler months of the year in tropical and subtropical areas, while warmer temperatures at other times of the year will promote survival [134]. B. salamandrivorans infection and disease dynamics are likewise dictated to great extent by environmental temperature. Infection intensities of 10000 zoospore equivalents at which mortality occurs [135] are reached twice as fast at $15^{\circ} \mathrm{C}$ than at $20^{\circ} \mathrm{C}$, while at $25^{\circ} \mathrm{C} \mathrm{B}$. salamandrivorans is unable to colonize skin [29].

B. dendrobatidis seems liable to attenuation. Strains that have been successively passaged on culture media quite rapidly display a weakened infectivity and pathogenicity when exposed to amphibians, which can however be partially restored by passage through an amphibian host [136].

\subsubsection{Impact of environmental factors}

Differential susceptibility to $B$. dendrobatidis observed in natural populations may be due to several abiotic, environmental factors such as season, temperature, elevation [133, 134, 137] and intensity of ultraviolet B (UV-B) radiation [138]. Especially high-elevation areas or regions with cool temperatures entail an increased risk for $B$. dendrobatidis-related declines and extinctions (e.g. [139]). Plausibly, these environmental factors may increase the vulnerability of an individual considerably, by changing the virulence of $B$. dendrobatidis and/or by altering the immune function of the host of the amphibian host.

The work of Schmeller et al. [57] illustrates well how both abiotic and biotic factors influence the probability of infection by $B$. dendrobatidis at population level. They observed a variation in prevalence of $B$. dendrobatidis among populations of common midwife toads (Alytes obstetricans) at different amphibian breeding sites in the French Pyrenees. At the majority of the breeding sites, prevalence of $B$. dendrobatidis infection was less than $5 \%$, while at only few sites prevalence ran up to more than $90 \%$. Both altitude and temperature correlated positively with prevalence and mortality but were not conclusive, as at sites with equivalent temperature regimes still substantial variation in prevalence and mortality was observed. At these particular sites, Schmeller et al. [57] found that prevalence of $B$. dendrobatidis correlates with the abundance and diversity of the aquatic microfauna in the mountain lakes. In this particular case, ciliates and rotifers were found to predate on the aquatic infectious zoospores, and lowered the environmental abundance of $B$. dendrobatidis. Also microcrustacean zooplankton e.g. water fleas (Daphnia) [140] graze on the spores of this chytrid fungus and are known to reduce the risk on infection in aquatic environments. Variation in the occurrence of $B$. dendrobatidis might as well coincide with variation in other biotic factors including the macroinvertebrate community structure (e.g., midge larvae, dragonflies, waterbugs and snails) [141] and the presence of green algae that interfere with $B$. dendrobatidis, either physically or by allelopathy (the release of secondary metabolites that are detrimental for $B$. dendrobatidis) [140]. Additional research in this field is necessary to fully comprehend the impact of these biotic factors.

\subsubsection{Co-infection with multiple pathogens}

So far, this review has focused on single pathogen interactions. In reality, amphibian hosts may be exposed to various pathogens including viruses, bacteria, non-chytrid fungi or helminths that may also cause severe pathology and mortality. In captive amphibians, chytridiomycosis due to $B$. dendrobatidis has been found concomitantly with e.g. Ranavirus [142], Chlamydia pneumoniae [143], Aeromonas hydrophila [144] and Mycobaterium spp. [144] infection. Also in the wild, co-infection with $B$. dendrobatidis and Ranavirus has been observed [145]. In these cases, it is difficult to determine which pathogen contributes most to morbidity and mortality or to distinguish between primary and secondary pathogen. Indeed, information on how 
interactions between co-occurring pathogens affect disease severity are quite scarce. A positive correlation has been found between infection by Ranavirus and B. dendrobatidis in some neotropical Hylidae, Craugastoridae and Dendrobatidae. Particularly in Craugaster fitzingeri, the odds of finding Ranavirus were significantly higher in individuals infected with $B$. dendrobatidis [145]. Also lower survival is observed in Pseudacris regilla larvae experimentally exposed to both the nematode Ribeiroia and $B$. dendrobatidis than when exposed to one of either pathogens [146]. But as discussed earlier, also abiotic environmental stressors may strongly influence disease susceptibility and might control whether interactions between pathogens occur.

In the same light, the question what would happen if both potentially lethal fungi are present in the same amphibian population is quite worry some. In Brazil, the co-occurrence of the hypervirulent $B d G \mathrm{GL}$ and an endemic lineage $(B d \mathrm{Bz})$ resulted in a moderate but steady prevalence, suggestive for tempering of the most lethal lineage [46]. Besides, co-occurrence gave also rise to hybridization between both $B$. dendrobatidis lineages $[20,21]$. In the Netherlands and Belgium, both $B$. salamandrivorans and $B$. dendrobatidis are present in native amphibian populations. While Dutch and Belgian amphibian communities are in coexistence with $B$. dendrobatidis [8], the newly emerged $B$. salamandrivorans has caused rapid mortality in Dutch fire salamander populations $[12,13]$. The crucial question is whether coinfection by both fungi will reinforce or on the contrary temper the high lethality of B. salamandrivorans. In case and urges for appropriate measures to prevent and control local chytridiomycosis outbreaks.

\section{Conclusions}

We have summarized all key features and most striking dissimilarities between both pathogenic chytrid fungi in a flashcard (Fig. 11). It is clear that many factors make $B$. dendrobatidis a significant concern, including its global distribution, its rapid spread, high virulence, and broad host range leading to considerable losses in amphibian biodiversity. A sobering development involves the recent emergence of $B$. salamandrivorans. Given the high susceptibility of salamanders and the current expansion of this fungus' range in Europe, B. salamandrivorans poses an unprecedented threat to, at least, the western Palearctic salamander diversity. Despite the effort of various research groups to unravel the complex interactions between the chytrid pathogens, their host and the environment, there are still knowledge gaps that need to be addressed. Several big challenges for future work that came up to the fore in the review are: (1) understanding of the basic biology of these chytrid fungi, e.g. cell membrane architecture/composition might be a key factor accounting for substantial differences between both fungi and their interaction with the host; (2) elucidation of the whole infection process of both chytrid species at cellular and molecular level; (3) the further study of mechanisms driving the infection dynamics of both fungi; (4) identification of carriers and non-amphibian vectors, and other abiotic factors promoting pathogen persis-

Flash card pathogenic chytrids

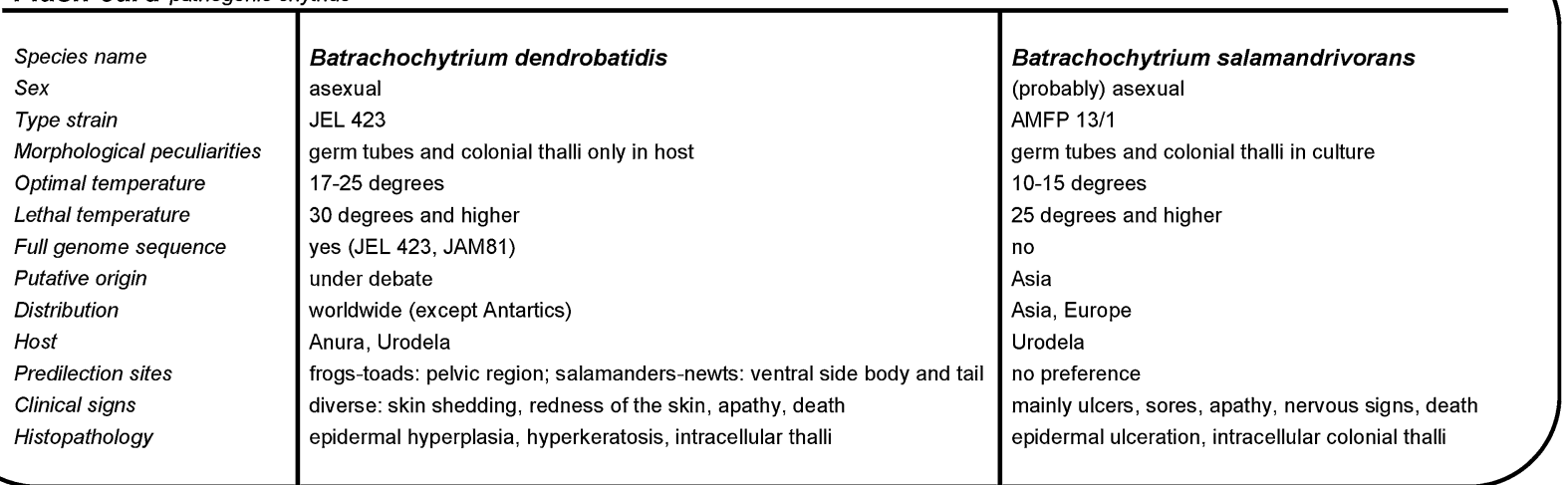

Fig. 11 Flash card of the pathogenic chytrid fungi. Overview of the key features and most striking dissimilarities between the pathogenic chytrid fungi B. dendrobatidis and B. salamandrivorans (2015)

of reinforcement, the native species richness is at stake tence in the environment; (5) continued global mapping of distribution, prevalence and genetic diversity 
of $B$. dendrobatidis and in particular B. salamandrivorans, with special attention to areas where both pathogens might co-occur. A thorough understanding of these aspects is of vital importance, to predict future disease scenarios and for the further development of efficient mitigation and curative measures to combat chytridiomycosis.

\section{Additional files}

Additional file 1. Colonization of keratinous geese squamae by B. salamandrivorans. Experimental set-up and results from in vitro experiments examining the ability of $B$. salamandrivorans to adhere and proliferate on kerationous toe scales of waterfowl.

Additional file 2. Experimental infection of urodelan larvae by $B$. salamandrivorans. Experimental set-up and results from in vivo infection experiments examining the ability of B. salamandrivorans to infect Salamandra salamandra and Discoglossus scovazzi larvae.

Additional file 3. Chemotaxis of $B$. dendrobatidis towards amphibian skin mucus. Experimental set-up and results from in vitro experiments examining chemotaxis of $B$. dendrobatidis towards skin mucus isolated from Xenopus laevis.

Additional file 4. Chemotaxis of $B$. dendrobatidis towards free integumental sugars. Experimental set-up and results from in vitro experiments examing chemotaxis of $B$. dendrobatidis towards the free integumental sugars a-L-fucose, a-D-N-acetylgalactosamine, $\beta$-D-N-acetylglucosamine, $\mathrm{N}$-acetylneuraminic acid or sialic acid, a-D-galactose and a-D-mannose.

Additional file 5. In vitro inhibition of $B$. dendrobatidis zoospores by amphibian skin mucus. Experimental procedures and results from in vitro assays quantifying of the zoosporicidal effect exerted by skin mucus from Xenopus laevis. Inhibition of $B$. dendrobatidis zoospores was quantified both visually by inverted microscopy and using EMA-qPCR.

Additional file 6. Adhesion of B. dendrobatidis to Xenopus laevis skin Experimental procedures of in vitro experiments examining adhesion of $B$. dendrobatidis zoospores to skin explants of Xenopus laevis using scanning electron microscopy.

Additional file 7. Quantification of lysozyme in amphibian skin mucus and evaluation of its activity against $B$. dendrobatidis. Experimental procedures and results from an assay quantifying lysozyme concentrations in skin mucus from Xenopus laevis and in vitro assays quantifying the activity of lysozyme from chicken egg white against $B$. dendrobatidis both visually by inverted microscopy and using EMA-qPCR.

\section{Authors' contributions}

PVR conceived and carried out the experimental studies, designed the linedrawings and drafted the manuscript; AM conceived and carried out the experimental studies and critically revised the manuscript; $\mathrm{FH}$ critically revised the manuscript; FP conceived the experimental studies and critically revised the manuscript. All authors read and approved the final manuscript.

\section{Acknowledgements}

DrWard De Spiegelaere and Prof. Dr. Wim Van den Broeck of the Department of Morphology of the Faculty of Veterinary Medicine (Ghent University) are gratefully acknowledged for their expertise in SEM. Financial support of PVR is funded by the Ghent University Special Research Fund (BOF13/PDO/130).

\section{Competing interests}

The authors declare that they have no competing interests.

Received: 15 July 2015 Accepted: 5 October 2015

Published online: 25 November 2015

\section{References}

1. IUCN (2015) IUCN Red List of Threatened Species. Version 2015-3. http://www.iucnredlist.org. Accessed 19 Sept 2015

2. Gascon C, Collins JP, Moore RD, Church DR, McKay JE, Mendelson JR III (2007) Amphibian conservation action plan. IUCN/SSC Amphibian Specialist Group, Gland

3. Berger $L$, Speare R, Daszak P, Green DE, Cunningham AA, Goggin $C L$, Slocombe R, Ragan MA, Hyatt AD, McDonald KR, Hines HB, Lips KR, Marantelli G, Parkes H (1998) Chytridiomycosis causes amphibian mortality associated with population declines in the rain forests of Australia and Central America. Proc Natl Acad Sci U S A 95:9031-9036

4. Lips KR, Brem F, Brenes R, Reeve JD, Alford RA, Voyles J, Carey C, Livo L, Pessier AP, Collins JP (2006) Emerging infectious disease and the loss of biodiversity in a Neotropical amphibian community. Proc Natl Acad Sci U S A 103:3165-3170

5. Campbell CR, Voyles J, Cook DI, Dinudom A (2012) Frog skin epithelium: electrolyte transport and chytridiomycosis. Int J Biochem Cell Biol 44:431-434

6. Searle CL, Gervasi SS, Hua J, Hammond Jl, Relyea RA, Olson DH, Blaustein AR (2011) Differential host susceptibility to Batrachochytrium dendrobatidis, an emerging amphibian pathogen. Conserv Biol 25:965-974

7. Fisher MC, Garner TWJ, Walker SF (2009) Global emergence of Batrachochytrium dendrobatidis and amphibian chytridiomycosis in space, time, and host. Ann Rev Microbiol 63:291-310

8. Spitzen-Van Der Sluijs A, Martel A, Hallmann CA, Bosman W, Garner TW, Van Rooij P, Jooris R, Haesebrouck F, Pasmans F (2014) Environmental determinants of recent endemism of Batrachochytrium dendrobatidis infections in amphibian assemblages in the absence of disease outbreaks. Conserv Biol 28:1302-1311

9. Martel A, Fard MS, Van Rooij P, Jooris R, Boone F, Haesebrouck F, Van Rooij D, Pasmans F (2012) Road-killed Common Toads (Bufo bufo) in Flanders (Belgium) reveal low prevalence of Ranaviruses and Batrachochytrium dendrobatidis. J Wildl Dis 48:835-839

10. Pasmans F, Muijsers M, Maes S, Van Rooij P, Brutyn M, Ducatelle R, Haesebrouck F, Martel A (2010) Chytridiomycosis related mortality in a midwife toad (Alytes obstetricans) in Belgium. Vlaams Diergen Tijds 79:460-462

11. Tobler U, Schmidt BR (2010) Within- and among-population variation in chytridiomycosis-induced mortality in the toad Alytes obstetricans. PLoS One 5:e10927

12. Spitzen-van der Sluijs A, Spikmans F, Bosman W, de Zeeuw M, van der Meij T, Goverse E, Kik M, Pasmans F, Martel A (2013) Rapid enigmatic decline drives the fire salamander (Salamandra salamandra) to the edge of extinction in the Netherlands. Amphibia Reptilia 34:233-239

13. Martel A, Spitzen-van der Sluijs A, Blooi M, Bert W, Ducatelle R, Fisher MC, Woeltjes A, Bosman W, Chiers K, Bossuyt F, Pasmans F (2013) Batrachochytrium salamandrivorans sp. nov. causes lethal chytridiomycosis in amphibians. Proc Natl Acad Sci U S A 110:15325-15329

14. Martel A, Blooi M, Adriaensen C, Van Rooij P, Beukema W, Fisher MC, Farrer RA, Schmidt BR, Tobler U, Goka K, Lips KR, Muletz C, Zamudio KR, Bosch J, Lötters S, Wombwell E, Garner TW, Cunningham AA, Spitzenvan der Sluijs A, Salvidio S, Ducatelle R, Nishikawa K, Nguyen TT, Kolby JE, Van Bocxlaer I, Bossuyt F, Pasmans F (2014) Recent introduction of a chytrid fungus endangers Western Palearctic salamanders. Science 346:630-631

15. Sabino-Pinto J, Bletz M, Hendrix R, Bina Perl RG, Martel A, Pasmans F, Lötters S, Mutschmann F, Schmeller DS, Schmidt BR, Veith M, Wagner N, Vences M, Steinfartz S. First detection of the emerging fungal pathogen Batrachochytrium salamandrivorans in Germany. Amphibia-Reptilia. doi:10.1163/15685381-00003008 (in press)

16. Longcore JE, Pessier AP, Nichols DK (1999) Batrachochytrium dendrobatidis gen et sp nov, a chytrid pathogenic to amphibians. Mycologia 91:219-227

17. Barr DJS (2001) Chytridiomycota. In: McLaughlin DJ, McLaughlin EG, Lemke PA (eds) The Mycota VII, Part A: systematics and evolution. Springer, Heidelberg, pp 93-112

18. Plehn M (1920) Neue Parasiten in Haut and Kiemen von Fischen. Ichthyochytrium und Mucophilus Zentralblatt für Bakteriologie und Parasitenkunde Abteilung 1(85):275-281 
19. Farrer RA, Weinert LA, Bielby J, Garner TWJ, Balloux F, Clare F, Bosch J, Cunningham AA, Weldon C, du Preez LH, Anderson L, Kosakovsky Pond SL, Shahar-Golan R, Henk DA, Fisher MC (2011) Multiple emergences of genetically diverse amphibian infecting chytrids include a globalized hypervirulent recombinant lineage. Proc Natl Acad Sci U S A 108:18732-18736

20. Schloegel LM, Toledo LF, Longcore JE, Greenspan SE, Vieira CA, Lee M, Zhao S, Wangen C, Ferreira CM, Hipolito M, Davies AJ, Cuomo CA, Daszak P, James TY (2012) Novel, panzootic and hybrid genotypes of amphibian chytridiomycosis associated with the bullfrog trade. Mol Ecol 21:5162-5177

21. Rosenblum EB, James TY, Zamudio KR, Poorten TJ, llut D, Rodriguez D, Eastman JM, Richards-Hrdlicka K, Joneson S, Jenkinson TS, Longcore JE, Parra Olea G, Toledo LF, Arellano ML, Medina EM, Restrepo S, Flechas SV, Berger L, Briggs CJ, Stajich JE (2013) Complex history of the amphibiankilling chytrid fungus revealed with genome resequencing data. Proc Natl Acad Sci U S A 110:9385-9390

22. Farrer RA, Henk DA, Garner TW, Balloux F, Woodhams DC, Fisher MC (2013) Chromosomal copy number variation, selection and uneven rates of recombination reveal cryptic genome diversity linked to pathogenicity. PLoS Genet 9:e1003703

23. Berger L, Hyatt AD, Speare R, Longcore JE (2005) Life cycle stages of the amphibian chytrid Batrachochytrium dendrobatidis. Dis Aquat Organ 68:51-63

24. Van Rooij P, Martel A, D'Herde K, Brutyn M, Croubels S, Ducatelle R, Haesebrouck F, Pasmans F (2012) Germ tube mediated invasion of Batrachochytrium dendrobatidis inamphibian skin is host dependent. PLoS One 7:e41481

25. Greenspan SE, Longcore JE, Calhoun AJ (2012) Host invasion by Batrachochytrium dendrobatidis: fungal and epidermal ultrastructure in model anurans. Dis Aquat Organ 100:201-210

26. Piotrowski JS, Annis SL, Longcore JE (2004) Physiology of Batrachochytrium dendrobatidis, a chytrid pathogen of amphibians. Mycologia 96:9-15

27. Johnson ML, Berger L, Philips L, Speare R (2003) Fungicidal effects of chemical disinfectants, UV light, desiccation and heat on the amphibian chytrid Batrachochytrium dendrobatidis. Dis Aquat Organ 57:255-260

28. Garmyn A, Van Rooij P, Pasmans F, Hellebuyck T, Van Den Broeck W, Haesebrouck F, Martel A (2012) Waterfowl: potential environmental reservoirs of the chytrid fungus Batrachochytrium dendrobatidis. PLoS One $7:$ e35038

29. Blooi M, Martel A, Haesebrouck F, Vercammen F, Bonte D, Pasmans F (2015) Treatment of urodelans based on temperature dependent infection dynamics of Batrachochytrium salamandrivorans. Sci Rep 5:8037

30. McMahon TA, Brannelly LA, Chatfield MWH, Johnson PTJ, Joseph MB, McKenzie VJ, Richards-Zawacki CL, Venesky MD, Rohr JR (2013) Chytrid fungus Batrachochytrium dendrobatidis has nonamphibian hosts and releases chemicals that cause pathology in absence of infection. Proc Natl Acad Sci U S A 110:210-215

31. Spatial epidemiology Bd-maps. Available: http://www.bd-maps.net. Accessed 2 Dec 2014

32. Olson DH, Aanensen DM, Ronnenberg KL, Powell Cl, Walker SF, Bielby J, Garner TW, Weaver G, Bd Mapping Group, Fisher MC (2013) Mapping the Global Emergence of Batrachochytrium dendrobatidis, the Amphibian Chytrid Fungus. PLoS One 8:e56802

33. Gower DJ, Doherty-Bone T, Loader SP, Wilkinson M, Kouete MT, Tapley B, Orton F, Daniel OZ, Wynne F, Flach E, Müller H, Menegon M, Stephen I, Browne RK, Fisher MC, Cunningham AA, Garner TW (2013) Batrachochytrium dendrobatidis infection and lethal chytridiomycosis in caecilian amphibians (Gymnophiona). EcoHealth 10:173-183

34. Cheng TL, Rovito SM, Wake DB, Vredenburg VT (2011) Coincident mass extirpation of neotropical amphibians with the emergence of the infectious fungal pathogen Batrachochytrium dendrobatidis. Proc Natl Acad Sci U S A 108:9502-9507

35. Rachowicz LJ, Knapp RA, Morgan JA, Stice MJ, Vredenburg VT, Parker JM, Briggs CJ (2006) Emerging infectious disease as a proximate cause of amphibian mass mortality. Ecology 87:1671-1683

36. Bosch J, Martinez-Solano I (2006) Chytrid fungus infection related to unusual mortalities of Salamandra salamandra and Bufo bufo in Peñalara National Park, Spain. Oryx 40:84-89
37. Muletz C, Caruso NM, Fleischer RC, McDiarmid RW, Lips KR (2014) Unexpected rarity of the pathogen Batrachochytrium dendrobatidis in Appalachian Plethodon Salamanders: 1957-2011. PLoS One 9:e103728

38. Zhu W, Bai C, Wang S, Soto-Azat C, Li X, Liu X, Li Y (2014) Retrospective survey of museum specimens reveals historically widespread presence of Batrachochytrium dendrobatidis in China. EcoHealth 11:241-250

39. Bales EK, Hyman OJ, Loudon AH, Harris RN, Lipps G, Chapman E, Roblee K, Kleopfer JD, Terrell KA (2015) Pathogenic chytrid fungus Batrachochytrium dendrobatidis, but not B. salamandrivorans, detected on eastern hellbenders. PLoS One 10:e0116405

40. Bosman W, Creemers RCM, Spitzen-van der Sluijs A, Zollinger R (2015) Monitoring van de vuursalamander in 2013 en 2014. Stichting RAVON, Nijmegen

41. Cunningham AA, Beckmann K, Perkins M, Fitzpatrick L, Cromie R, Redbond J, O'Brien MF, Ghosh P, Shelton J, Fisher MC (2015) Emerging disease in UK amphibians. Vet Rec 176:468

42. Weldon C, du Preez LH, Hyatt AD, Muller R, Speare R (2004) Origin of the amphibian chytrid fungus. Emerg Infect Dis 10:2100-2105

43. James TY, Litvintseva AP, Vilgalys R, Morgan JAT, Taylor JW, Fisher MC, Berger L, Weldon C, du Preez L, Longcore JE (2009) Rapid global expansion of the fungal disease chytridiomycosis into declining and healthy amphibian populations. PLoS Pathog 5:e1000458

44. Bai CM, Liu X, Fisher MC, Garner TWJ, Li YM (2012) Global and endemic Asian lineages of the emerging pathogenic fungus Batrachochytrium dendrobatidis widely infect amphibians in China. Divers Distrib 18:307-318

45. Fong JJ, Cheng TL, Bataille A, Pessier AP, Waldman B, Vredenburg VT (2015) Early 1900s detection of Batrachochytrium dendrobatidis in Korean amphibians. PLoS One 10:e0115656

46. Rodriguez D, Becker CG, Pupin NC, Haddad CF, Zamudio KR (2014) Long-term endemism of two highly divergent lineages of the amphibian-killing fungus in the Atlantic Forest of Brazil. Mol Ecol 23:774-787

47. Lj Rachowicz, Hero JM, Alford RA, Taylor JW, Morgan JAT, Vredenburg VT, Collins JP, Briggs CJ (2005) The novel and endemic pathogen hypothesis: competing explanations for the origin of emerging infectious diseases. Conserv Biol 19:1441-1448

48. Soto-Azat C, Clarke BT, Poynton JC, Cunningham AA (2010) Widespread historical presence of Batrachochytrium dendrobatidis in African pipid frogs. Divers Distrib 16:126-131

49. Fisher MC, Garner TWJ (2007) The relationship between the emergence of Batrachochytrium dendrobatidis, the international trade in amphibians and introduced amphibian species. Fungal Biol Rev 21:2-9

50. Herrel A, van der Meijden A (2014) An analysis of the live reptile and amphibian trade in the USA compared to the global trade in endangered species. Herpetol J 24:103-110

51. Garner TWJ, Perkins MW, Govindarajulu P, Seglie D, Walker S, Cunningham AA, Fisher MC (2006) The emerging amphibian pathogen Batrachochytrium dendrobatidis globally infects introduced populations of the North American bullfrog, Rana catesbeiana. Biol Lett 2:455-459

52. Kolby JE, Smith KM, Berger L, Karesh WB, Preston A, Pessier AP, Skerratt LF (2014) First evidence of amphibian chytrid fungus (Batrachochytrium dendrobatidis) and ranavirus in Hong Kong amphibian trade. PLoS One 9:e90750

53. Rowley $\mathrm{J} \mathrm{J}$, Alford RA (2007) Behaviour of Australian rain forest stream frogs may affect the transmission of chytridiomycosis. Dis Aquat Organ 77:1-9

54. Reeder NMM, Pessier AP, Vredenburg VT (2012) A reservoir species for the emerging amphibian pathogen Batrachochytrium dendrobatidis thrives in a landscape decimated by disease. PLoS One 7:e33567

55. Johnson ML, Speare R (2003) Survival of Batrachochytrium dendrobatidis in water: quarantine and disease control implications. Emerg Infect Dis 9:922-925

56. Johnson ML, Speare R (2005) Possible modes of dissemination of the amphibian chytrid Batrachochytrium dendrobatidis in the environment. Dis Aquat Organ 65:181-186

57. Schmeller DS, Blooi M, Martel A, Garner TW, Fisher MC, Azemar F, Clare FC, Leclerc C, Jäger L, Guevara-Nieto M, Loyau A, Pasmans F (2014) Microscopic aquatic predators strongly affect infection dynamics of a globally emerged pathogen. Curr Biol 24:176-180

58. Kilburn VL, Ibanez R, Green DM (2011) Reptiles as potential vectors and hosts of the amphibian pathogen Batrachochytrium dendrobatidis in Panama. Dis Aquat Organ 97:127-134 
59. Rachowicz LJ, Vredenburg VT (2004) Transmission of Batrachochytrium dendrobatidis within and between amphibian life stages. Dis Aquat Organ 61:75-83

60. Hanlon SM, Lynch KJ, Kerby J, Parris MJ (2015) Batrachochytrium dendrobatidis exposure effects on foraging efficiencies and body size in anuran tadpoles. Dis Aquat Organ 112:237-242

61. Pessier AP (2008) Amphibian chytridiomycosis. In: Fowler ME, Miller ER (eds) Zoo and Wild Animal Medicine. Current therapy, vol 6. Saunders Elsevier, St. Louis, pp 137-143

62. Berger L, Speare R, Skerratt L (2005) Distribution of Batrachochytrium dendrobatidis and pathology in the skin of green tree frogs (Litoria caerulea) with severe chytridiomycosis. Dis Aquat Organ 68:65-70

63. Puschendorf R, Bolaños F (2006) Detection of Batrachochytrium dendrobatidis in Eleutherodactylus fitzingeri: effects of skin sample location and histologic stain. J Wildl Dis 42:301-306

64. Van Rooij P, Martel A, Nerz J, Voitel S, Van Immerseel F, Haesebrouck F, Pasmans F (2011) Detection of Batrachochytrium dendrobatidis in Mexican bolitoglossine salamanders using an optimal sampling protocol. EcoHealth 8:237-243

65. Pasmans F, Zwart R, Hyatt AD (2004) Chytridiomycosis in the Central American bolitoglossine salamander (Bolitoglossa dofleini). Vet Rec 154:153

66. Marantelli G, Berger L, Speare R, Keegan L (2004) Distribution of the amphibian chytrid Batrachochytrium dendrobatidis and keratin during tadpole development. Pacific Conserv Biol 10:173-179

67. McGuckin MA, Lindén SK, Sutton P, Florin TH (2011) Mucin dynamics and enteric pathogens. Nat Rev Microbiol 9:265-278

68. Moss AS, Reddy NS, Dortaj IM, Francisco MJS (2008) Chemotaxis of the amphibian pathogen Batrachochytrium dendrobatidis and its response to a variety of attractants. Mycologia 100:1-5

69. Meyer W, Seegers U, Schnapper A, Neuhaus H, Himstedt W, ToepferPetersen (2007) Possible antimicrobial defense by free sugars on the epidermal surface of aquatic vertebrates. Aquat Biol 1:167-175

70. Rollins-Smith LA, Ramsey JP, Reinert LK, Woodhams DC, Livo LJ, Carey C (2009) Immune defenses of Xenopus laevis against Batrachochytrium dendrobatidis. Front Biosci 1:68-91

71. Baldo A, Monod M, Mathy A, Cambier L, Bagut ET, Defaweux V, Symoens F, Antoine N, Mignon B (2012) Mechanisms of skin adherence and invasion by dermatophytes. Mycoses 55:218-223

72. Rosenblum EB, Stajich JE, Maddox N, Eisen MB (2008) Global gene expression profiles for life stages of the deadly amphibian pathogen Batrachochytrium dendrobatidis. Proc Natl Acad Sci U S A 105:17034-17039

73. Rosenblum EB, Poorten TJ, Settles M, Murdoch GK (2012) Only skin deep: shared genetic response to the deadly chytrid fungus in susceptible frog species. Mol Ecol 21:3110-3120

74. Abramyan J, Stajich JE (2012) Species-specific chitin binding module 18 expansion in the amphibian pathogen Batrachochytrium dendrobatidis. MBio 3:e00112-e00150

75. Van Rooij P, Martel A, Brutyn M, Maes S, Chiers K, Van Waeyenberghe L, Croubels S, Haesebrouck F, Pasmans F (2010) Development of in vitro models for a better understanding of the early pathogenesis of Batrachochytrium dendrobatidis infections in amphibians. Altern Lab Anim 38:519-528

76. McMahon TA, Rohr JR (2015) Transition of chytrid dungus infection from mouthparts to hind limbs during amphibian metamorphosis. EcoHealth 12:188-193

77. Heatwhole H, Barthalamus GT (1994) Amphibian Biology, vol 1. Surrey Beaty and Sons, Chipping Norton

78. Joneson S, Stajich JE, Shiu SH, Rosenblum EB (2011) Genomic transition to pathogenicity in Chytrid fungi. PLoS Pathog 7:e1002338

79. Moss AS, Carty N, Francisco MJS (2010) Identification and partial characterization of an elastolytic protease in the amphibian pathogen Batrachochytrium dendrobatidis. Dis Aquat Organ 92:149-158

80. Brutyn M, D'Herde K, Dhaenens M, Van Rooij P, Verbrugghe E, Hyatt AD Croubels S, Deforce D, Ducatelle R, Haesebrouck F, Martel A, Pasmans F (2012) Batrachochytrium dendrobatidis zoospore secretions rapidly disturb intercellular junctions in frog skin. Fungal Genet Biol 49:830-837

81. Zasloff M (2002) Antimicrobial peptides of multicellular organisms. Nature 415:389-393
82. Conlon MJ, Iwamuro S, King JD (2009) Dermal cytolytic peptides and the system of innate immunity in anurans. Trends Comp Endocrinol Ann NY Acad Sci 1163:75-82

83. Woodhams DC, Ardipradja K, Alford RA, Marantelli G, Reinert LK, RollinsSmith LA (2007) Resistance to chytridiomycosis varies among amphibian species and is correlated with skin peptide defenses. Anim Conserv 10:409-417

84. Rollins-Smith LA (2009) The role of amphibian antimicrobial peptides in protection of amphibians from pathogens linked to global amphibian declines. Biochim Biophys Acta 1788:1593-1599

85. Ramsey JP, Reinert LK, Harper LK, Woodhams DC, Rollins-Smith LA (2010) Immune defenses against Batrachochytrium dendrobatidis, a fungus Linked to global amphibian declines, in the South African Clawed Frog, Xenopus laevis. Infect Immun 78:3981-3992

86. Rollins-Smith LA, Woodhams DC, Reinert LK, Vredenburg VT, Briggs CJ, Nielsen PF, Conlon JM (2006) Antimicrobial peptide defenses of the mountain yellow-legged frog (Rana muscosa). Dev Comp Immunol 30:831-842

87. Tennessen JA, Woodhams DC, Chaurand P, Reinert LK, Billheimer D, Shyr Y, Caprioli RM, Blouin MS, Rollins-Smith LA (2009) Variations in the expresses antimicrobial peptide repertoire of northern leopard frog (Rana pipiens) populations suggest intraspecies differences in resistance to pathogens. Dev Comp Immunol 33:1247-1257

88. Daum JN, Davis LR, Bigler L, Woodhams DC (2012) hybrid advantage in skin peptide immune defenses of water frogs (Pelophylax esculentus) at risk from emerging pathogens. Inf Gen Evol 12:1854-1864

89. Pask JD, Woodhams DC, Rollins-Smith LA (2012) The ebb and flow of antimicrobial skin peptides defends northern leopard frogs (Rana pipiens) against chytridiomycosis. Glob Change Biol 18:1231-1238

90. Sheafor B, Davidson EW, Parr L, Rollins-Smith L (2008) Antimicrobial peptide defenses in the salamander Ambystoma tigrinum, against emerging amphibian pathogens. J Wildl Dis 44:226-236

91. Pasmans F, Van Rooij P, Blooi M, Tessa G, Bogaerts S, Sotgiu G, Garner TW, Fisher MC, Schmidt BR, Woeltjes T, Beukema W, Bovero S, Adriaensen C, Oneto F, Ottonello D, Martel A, Salvidio S (2013) Resistance to chytridiomycosis in European plethodontid salamanders of the genus Speleomantes. PLoS One 8:e63639

92. Meng P, Yang S, Shen C, Jiang K, Rong M, Lai R (2013) The first salamander defensin antimicrobial peptide. PLoS One 8:e83044

93. Brucker RM, Harris RN, Schwantes CR, Gallaher TN, Flaherty DC, Lam BA, Minbiole KPC (2008) Amphibian chemical defense: antifungal metabolites of the microsymbiont Janthinobacterium lividum on the salamander Plethodon cinereus. J Chem Ecol 34:1422-1429

94. Myers JM, Ramsey JP, Blackman AL, Nichols EA, Minbiole KPC, Harris RN (2012) Synergistic inhibition of the lethal fungal pathogen Batrachochytrium dendrobatidis: the combined effect of symbiotic bacterial metabolites and antimicrobial peptides of the frog Rana muscosa. J Chem Ecol 8:958-965

95. Lam BA, Walke J, Vredenburg VT, Harris RN (2010) Proportion of individuals with anti-Batrachochytrium dendrobatidis skin bacteria is associated with population persistence in the frog Rana muscosa. Biol Conserv 143:529-531

96. Loudon AH, Holland JA, Umile TP, Burzynski EA, Minbiole KP, Harris RN (2014) Interactions between amphibians' symbiotic bacteria cause the production of emergent anti-fungal metabolites. Front Microbiol 5:441

97. Lam BA, Walton DB, Harris RN (2011) Motile zoospores of Batrachochytrium dendrobatidis move away from antifungal metabolites produced by amphibian skin bacteria. EcoHealth 8:36-45

98. Harris RN, Lauer A, Simon MA, Banning JL, Alford RA (2009) Addition of antifungal skin bacteria to salamanders ameliorates the effects of chytridiomycosis. Dis Aquat Organ 83:11-16

99. Antwis RE, Preziosi RF, Harrison XA, Garner TWJ (2015) Amphibian symbiotic bacteria do not show a universal ability to inhibit growth of the global panzootic lineage of Batrachochytrium dendrobatidis. Appl Environ Microbiol 81:3706-3711

100. Rosenblum EB, Poorten TJ, Settles M, Murdoch GK, Robert J, Maddox N, Eisen MB (2009) Genome-wide transcriptional response of Silurana (Xenopus) tropicalis to infection with the deadly chytrid fungus. PLoS One 4:e6494

101. Ellison AR, Savage AE, DiRenzo GV, Langhammer P, Lips KR, Zamudio KR (2014) Fighting a losing battle: vigorous immune response countered 
by pathogen suppression of host defenses in the chytridiomycosissusceptible frog Atelopus zeteki. G3(4):1275-1289

102. Ribas L, Li MS, Doddington BJ, Robert J, Seidel JA, Kroll JS, Zimmerman LB, Grassly NC, Garner TW, Fisher MC (2009) Expression profiling the temperature-dependent amphibian response to infection by Batrachochytrium dendrobatidis. PLoS One 4:e8408

103. Stice MJ, Briggs CJ (2010) Immunization is ineffective at preventing infection and mortality due to the amphibian chytrid fungus Batrachochytrium dendrobatidis. J Wildl Dis 46:70-77

104. McMahon TA, Sears BF, Venesky MD, Bessler SM, Brown JM, Deutsch K, Halstead NT, Lentz G, Tenouri N, Young S, Civitello DJ, Ortega N, Fites JS, Reinert LK, Rollins-Smith LA, Raffel TR, Rohr JR (2014) Amphibians acquire resistance to live and dead fungus overcoming fungal immunosuppression. Nature 511:224-227

105. Cashins SD, Grogan LF, McFadden M, Hunter D, Harlow PS, Berger L, Skerratt LF (2013) Prior infection does not improve survival against the amphibian disease Chytridiomycosis. PLoS One 8:e56747

106. Woodhams DC, Bell SC, Kenyon N, Alford RA, Rollins-Smith LA (2012) Immune evasion or avoidance: fungal skin infection linked to reduced defence peptides in Australian green-eyed treefrogs, Litoria serrata. Fungal Biol 116:1203-1211

107. Young S, Whitehorn P, Berger L, Skerratt LF, Speare R, Garland S, Webb $R$ (2014) Defects in host immune function in tree frogs with chronic chytridiomycosis. PLoS One 9:e107284

108. Fites JS, Ramsey JP, Holden WM, Collier SP, Sutherland DM, Reinert LK, Gayek AS, Dermody TS, Aune TM, Oswald-Richter K, Rollins-Smith LA (2013) The invasive chytrid fungus of amphibians paralyzes lymphocyte responses. Science 342:366-369

109. Fites JS, Reinert LK, Chappell TM, Rollins-Smith LA (2014) Inhibition of local immune responses by the frog-killing fungus Batrachochytrium dendrobatidis. Infect Immun 82:4698-4706

110. Thekkiniath JC, Zabet-Moghaddam M, San Francisco SK, San Francisco MJ (2013) A novel subtilisin-like serine protease of Batrachochytrium dendrobatidis is induced by thyroid hormone and degrades antimicrobial peptides. Fungal Biol 117:451-461

111. Nichols DK, Lamirande EW, Pessier AP, Longcore JE (2001) Experimental transmission of cutaneous chytridiomycosis in dendrobatid frogs. J Wildl Dis 37:1-11

112. Weinstein SB (2009) An aquatic disease on a terrestrial salamander: individual and population level effects of the amphibian chytrid fungus, Batrachochytrium dendrobatidis on Batrachoseps attenuates (Plethodontidae). Copeia 4:653-660

113. Vazquez VM, Rothermel BB, Pessier AP (2009) Experimental infection of North American plethodontid salamanders with the fungus Batrachochytrium dendrobatidis. Dis Aquat Organ 84:1-7

114. Thien TN, Martel A, Brutyn M, Bogaerts S, Sparreboom M, Haesebrouck F, Fisher MC, Beukema W, Van TD, Chiers K, Pasmans F (2013) A survey for Batrachochytrium dendrobatidis in endangered and highly susceptible Vietnamese salamanders (Tylototriton spp.). J Zoo Wildl Med 44:627-633

115. Bovero S, Sotgiu G, Angelini C, Doglio S, Gazzaniga E, Cunningham AA, Garner TWJ (2008) Detection of Chytridiomycosis Caused by Batrachochytrium dendrobatidis in the Endangered Sardinian Newt (Euproctus platycephalus) in Southern Sardinia, Italy. J Wild Dis 44:712-715

116. Solis R, Lobos G, Walker SF, Fisher M, Bosch J (2010) Presence of Batrachochytrium dendrobatidis in feral populations of Xenopus laevis in Chile. Biol Invasions 12:1641-1646

117. Woodhams DC, Hyatt AD, Boyle DG, Rollins-Smith LA (2008) The Northern leopard frog Rana pipiens is a widespread reservoir species harboring Batrachochytrium dendrobatidis in North America. Herpetol Rev 39:66-68

118. Savage AE, Zamudio KR (2011) MHC genotypes associate with resistance to a frog-killing fungus. Proc Natl Acad Sci U S A 108:16705-16710

119. Bataille A, Cashins SD, Grogan L, Skerratt LF, Hunter D, McFadden M, Scheele B, Brannelly LA, Macris A, Harlow PS, Bell S, Berger L, Waldman B (2015) Susceptibility of amphibians to chytridiomycosis is associated with MHC class II conformation. Proc Biol Sci 282:20143127

120. Luquet E, Garner TW, Lena JP, Bruel C, Joly P, Lengagne T, Grolet O, Plénet S (2012) Genetic erosion in wild populations makes resistance to a pathogen more costly. Evolution 66:1942-1952
121. Daskin JH, Alford RA, Puschendorf R (2011) Short-term exposure to warm microhabitats could explain amphibian persistence with Batrachochytrium dendrobatidis. PLoS One 6:e26215

122. Richards-Zawacki CL (2010) Thermoregulatory behaviour affects prevalence of chytrid fungal infection in a wild population of Panamanian golden frogs. Proc Biol Sci 277:519-528

123. Gabor CR, Fisher MC, Bosch J (2013) A non-invasive stress assay shows that tadpole populations infected with Batrachochytrium dendrobatidis have elevated corticosterone levels. PLoS One 8:e56054

124. Searle CL, Belden LK, Du P, Blaustein AR (2014) Stress and chytridiomycosis: exogenous exposure to corticosterone does not alter amphibian susceptibility to a fungal pathogen. J Exp Zool A Ecol Genet Physiol 321:243-253

125. Blaustein AR, Romansic JM, Scheessele EA, Han BA, Pessier AP, Longcore JE (2005) Interspecific variation in susceptibility of frog tadpoles to the pathogenic fungus Batrachochytrium dendrobatidis. Conserv Biol 19:1460-1468

126. Rollins-Smith LA, Ramsey JP, Pask JD, Reinert LK, Woodhams DC (2011) Amphibian immune defenses against chytridiomycosis: impacts of changing environments. Integr Comp Biol 51:552-562

127. Muths E, Scherer RD, Pilliod DS (2011) Compensatory effects of recruitment and survival when amphibian populations are perturbed by disease. J Appl Ecol 48:873-879

128. Scheele BC, Hunter DA, Skerratt LF, Branelly LA, Driscoll DA (2015) Low impact of chytridiomycosis on frog recruitment enables persistence in refuges despite high adult mortality. Biol Conserv 182:36-43

129. Briggs CJ, Knapp RA, Vredenburg VT (2010) Enzootic and epizootic dynamics of the chytrid fungal pathogen of amphibians. Proc Natl Acad Sci U S A 107:9695-9700

130. Venesky MD, Liu X, Sauer EL, Rohr JR (2014) Linking manipulative experiments to field data to test the dilution effect. J Anim Ecol 83:557-565

131. Berger L, Marantelli G, Skerratt LF, Speare R (2005) Virulence of the amphibian chytrid fungus, Batrachochytrium dendrobatidis, varies with the strain. Dis Aquat Organ 68:47-50

132. Fisher MC, Bosch J, Yin Z, Stead DA, Walker J, Selway L, Brown AJ, Walker LA, Gow NA, Stajich JE, Garner TW (2009) Proteomic and phenotypic profiling of the amphibian pathogen Batrachochytrium dendrobatidis shows that genotype is linked to virulence. Mol Ecol 18:415-429

133. Voyles J, Johnson LR, Briggs CJ, Cashins SC, Alford RA, Berger L, Skerratt LF, Speare R, Rosenblum EB (2012) Temperature alters reproductive life history patterns in Batrachochytrium dendrobatidis, a lethal pathogen associated with the global loss of amphibians. Ecol Evol 2:2241-2249

134. Berger L, Speare R, Hines HB, Marantelli G, Hyatt AD, McDonald KR, Skerratt LF, Olsen V, Clarke JM, Gillespie G, Mahony M, Sheppard N, Williams C, Tyler MJ (2004) Effect of season and temperature on mortality in amphibians due to chytridiomycosis. Aust Vet J 82:434-439

135. Blooi M, Pasmans F, Longcore JE, Spitzen-van der Sluijs A, Vercammen F, Martel A (2013) Duplex real-time PCR for rapid simultaneous detection of Batrachochytrium dendrobatidis and Batrachochytrium salamandrivorans in amphibian samples. J Clin Microbiol 51:4173-4177

136. Brem FM, Parris MJ, Padgett-Flohr GE (2013) Re-isolating Batrachochytrium dendrobatidis from an amphibian host increases pathogenicity in a subsequent exposure. PLoS One 8:e61260

137. Doddington BJ, Bosch J, Oliver JA, Grassly NC, Garcia G, Schmidt BR, Garner TWJ, Fisher MC (2013) Context dependent amphibian host population response to an invading pathogen. Ecology 94:1795-1804

138. Ortiz-Santaliestra ME, Fisher MC, Fernandez-Beaskoetxea S, FernandezBeneitez MJ, Bosch J (2011) Ambient ultraviolet B radiation and prevalence of infection by Batrachochytrium dendrobatidis in two amphibian species. Conserv Biol 25:975-982

139. Woodhams DC, Alford RA (2005) Ecology of chytridiomycosis in rainforest stream frog assemblages of tropical Queensland. Conserv Biol 19:1449-1459

140. Searle CL, Mendelson JR III, Green LE, Duffy MA (2013) Daphnia predation on the amphibian chytrid fungus and its impcats on disease risk in tadpoles. Ecol Evol 3:4129-4138

141. Strauss A, Smith KG (2013) Why does amphibian chytrid (Batrachochytrium dendrobatidis) not occur everywhere? An exploratory study in Missouri ponds. PLoS One 8:e76035

142. Kik M, Stege M, Boonyarittichaikij R, van Asten A (2012) Concurrent ranavirus and Batrachochytrium dendrobatidis infection in captive frogs 
(Phyllobates and Dendrobates species), The Netherlands, 2012: a first report. Vet J 194:247-249

143. Reed KD, Ruth GR, Meyer JA, Shukla SK (2000) Chlamydia pneumoniae infection in a breeding colony of African clawed frogs (Xenopus tropicalis). Emerg Infect Dis 6:196-199

144. Hill WA, Newman SJ, Craig L, Carter C, Czarra J, Brown JP (2010) Diagnosis of Aeromonas hydrophila, Mycobacterium species, and Batrachochytrium dendrobatidis in an African clawed frog (Xenopus laevis). J Am Assoc Lab Anim Sci 49:215-220

145. Whitfield SM, Geerdes E, Chacon I, Ballestero Rodriguez E, Jimenez RR, Donnelly MA, Kerby JL (2013) Infection and co-infection by the amphibian chytrid fungus and ranavirus in wild Costa Rican frogs. Dis Aquat Organ 104:173-178

146. Romansic JM, Johnson PTJ, Searle CL, Johnson JE, Tunstall T, Han BA, Rohr JR, Blaustein AR (2011) Individual and combined effects of multiple pathogens on Pacific treefrogs. Oecologia 166:1029-1041

147. Martel A, Van Rooij P, Vercauteren G, Baert K, Van Waeyenberghe L, Debacker P, Garner TW, Woeltjes T, Ducatelle R, Haesebrouck F Pasmans F (2011) Developing a safe antifungal treatment protocol to eliminate Batrachochytrium dendrobatidis from amphibians. Med Mycol 49:143-149

148. Boyle DG, Boyle DB, Olsen V, Morgan JA, Hyatt AD (2004) Rapid quantitative detection of chytridiomycosis (Batrachochytrium dendrobatidis) in amphibian samples using real-time Taqman PCR assay. Dis Aquat Organ 60:141-148

149. Blooi M, Martel A, Vercammen F, Pasmans F (2013) Combining ethidium monoazide treatment with real-time PCR selectively quantifies viable Batrachochytrium dendrobatidis cells. Fungal Biol 117:156-162

150. Hibbett DS, Binder M, Bischoff JF, Blackwell M, Cannon PF, Eriksson OE, Huhndorf S, James T, Kirk PM, Lücking R, Thorsten Lumbsch H, Lutzoni F, Matheny PB, McLaughlin DJ, Powell MJ, Redhead S, Schoch CL, Spatafora JW, Stalpers JA, Vilgalys R, Aime MC, Aptroot A, Bauer R, Begerow D, Benny GL, Castlebury LA, Crous PW, Dai YC, Gams W, Geiser DM et al. (2007) A higher-level phylogenetic classification of the Fungi. Myc Res 3:509-547

\section{Submit your next manuscript to BioMed Central and take full advantage of:}

- Convenient online submission

- Thorough peer review

- No space constraints or color figure charges

- Immediate publication on acceptance

- Inclusion in PubMed, CAS, Scopus and Google Scholar

- Research which is freely available for redistribution

Submit your manuscript at

www.biomedcentral.com/submit

() Biomed Central 